Türk Yönetim ve Ekonomi Araştırmaları Dergisi

Y11: 2021, Cilt: 2, Say1: 1, ss.56-76

\title{
Türkiye Cumhuriyeti Siyasal Sistemi ${ }^{1}$
}

\author{
Political System of the Republic of Turkey
}

Kamil GÖKSEL

Uluslararası İlişkiler Uzmanı

kmlgksl@gmail.com

https://orcid.org/0000-0001-6591-555X

\section{Doç. Dr. Ahmet TUNÇ}

Çanakkale Onsekiz Mart Üniversitesi Öğretim Üyesi

ahmetmalatyatunc@gmail.com

https://orcid.org/0000-0003-0106-2599
Makale Başvuru Tarihi / Received: 25.05.2021

Makale Kabul Tarihi / Accepted:29.06.2021

Makale Türü / Article Type: Araştırma Makalesi

\author{
Anahtar Kelimeler: \\ Türkiye, \\ Siyasal Sistem, \\ Başkanlık Sistemi, \\ Cumhurbaşkanlığ \\ Hükümet Sistemi
}

Keywords:

Turkey,

Political System,

Presidental System,

Presidentil Government System

\section{ÖZET}

Geçmişten günümüze yönetim kaynaklı siyasi krizlerin engellenmesi adına Türk siyasal sistemi birçok yöntemi denemiştir. Tarihsel süreç içerisinde gerek Osmanl dönemi gerekse Cumhuriyet dönemi içerisinde birçok yönetim sorunu ile karşı karşıya kalınmıştır. Ortaya çıkan sorunlar neticesinde ise istikrarsız yönetimlerle karşılaşılmış ve yeni hükümet sistemi arayışları ortaya çıkmıştır. Dolayısıyla her yeni anayasada farklı hükümet sisteminin uygulandı̆̆ görülmektedir. Ancak uygulanan sistemlerin ortaya çıtı̆̆ diğer ülkelere nazaran kendilerine özgü farklılıklar göstermektedir. Bu durumun Türk siyasal kültürünün geçmişten getirdiği birikim neticesinde her sistemin kendisine özgü yorumlanmasından kaynaklanmaktadır. Söz konusu süreçler bu çalışmada Türk siyasal sisteminin kurumsallaşması olarak nitelendirilmiştir. Bunun nedeni ise nihai halini, ortaya çıkan sorunların çözümü adına birçok revizyondan sonra almış olmasıdır. Alt başlıklarla ele alınacak tarihsel süreçle Osmanlı döneminden günümüze kadar olan değişiklikler incelenmiştir. Son hali ise Cumhurbaşkanlı̆̆ Hü̈kümet Sistemi olarak alan Türkiyénin mevcut sisteminin özellikleri, erklerin işleyişi, sistemin diğer öğeleri detaylı biçimde ele alınmıştır.

\section{ABSTRACT}

From past to present, the Turkish political system has tried many methods in order to prevent political crises stemming from the administration. In the historical process, many management problems have been faced both in the Ottoman period and the Republican period. As a result of the problems that arose, unstable administrations were encountered and the search for a new government system emerged. Therefore, it is seen that a different government system is applied in each new constitution. However, the systems applied differ from each other in comparison to other countries. This situation arises from the unique interpretation of each system as a result of the accumulation of Turkish political culture from the past. These processes are described as the institutionalization of the Turkish political system in this study. The reason for this is that it has taken its final form after many revisions in order to solve the problems that have arisen. The historical process, which will be discussed under the subtitles, and the changes from the Ottoman period to the present are examined. The features of the current system of Turkey, the last version of which is the Presidential Government System, the functioning of the powers, and other elements of the system are discussed in detail.

\footnotetext{
12020 yılında Kahramanmaraş Sütçü İmam Üniversitesi SBE Siyaset Bilimi ve Uluslararası İlişkiler ABD’da hazırlanan “'ABD’de Lobicilik Faliyetleri ve Türkiye'de Uygulanabilirliği' ' adlı yüksek lisans tezinin bir bölümünün gözden geçirilmiş ve güncellenmiş halidir.
} 


\section{GİRIŞ}

Türk Siyasal sisteminin tarihsel gelişimi ele alındığında yöneticilerin kurul toplantılarının ardından karar aldığı ve kararların da buradan çıktığı görülmektedir. Türk Devletlerinin neredeyse tamamında farklı bir biçimde isimlendirilen bu kurullar; Divan, Şura, Kurultay, Toy v.d. gibi birçok farklı biçimde isimlendirilmiş olsa da işlevi hep aynı kalmıştır. Ancak söz konusu danışma niteliğinde olan kurullar hiçbir zaman siyasi bağımsızlık kazanan ve üyelerinin doğrudan halk oyu ile seçildiği olmamıştır. Dolayısıyla bir parlamento görünümünden uzak olduğundan bahsetmek mümkündür. Bu kurullar danışma görevini yerine getiren ve ülkeyi yöneten kişi tarafindan oluşturulan bir kurul olma niteliğini Osmanlının son dönemlerine kadar korumuştur (Ağır, 2017: 184).

18 y.y sonlarına gelindiğinde ise dünyada yönetim alanında birçok değişiklik yaşanmaktadır. Fransa'da XI. Lousie, 17.y.y da Avusturya'da II. Joseph ve Rusya'da Katerina ile başlayan merkezileşme hareketleri Osmanlı'ya yansımamıştır. Bunda önemli olan sebeplerden birisi Tımar sisteminde ciddi bozulmaların meydana gelmesi ile ayanların güçlenerek merkezi idareyi zayıflatmasına neden olmuştur (Göktolga, 2013: 3). Bunun etkileri 1808 Senedi İttifak ile birlikte kendisini göstermektedir. Dönemin şartları dikkate alındığında Avrupalı diğer devletlere nazaran İstanbul yönetimin örgütlenmesinin zayıf kaldı̆̆g görülmektedir. Bunun önemli bir nedeni ise adem-i merkeziyetten yoksun yönetim anlayışının hakim olmasıdır. Ayrıca merkezi yönetimde zayıf olan örgütlenme neticesinde toplanan vergilerin çok cüzi bir miktarı merkeze ulaşmakta dolayısı ile ekonomik sıkıntılar baş göstermektedir. Eyaletlerde neredeyse padişahın yetkileri ile donatılan valiler merkeze karşı bir güç tehdidi haline gelmiş ve Mısır Valisi Kavalalı Mehmet Ali Paşa'nın isyanı gibi sonuçlar doğurmuştur. Bunun sonucunda ise Tanzimat Fermanı ilan edilerek bürokrasiyi güçlendirmek hedeflenmiştir. Dolayısı ile bu hareketi ilk modernleşme girişimleri olarak nitelendirmek mümkündür (Çilliler, 2019: 57). Bürokrasinin yeniden yapılanması harekatı olan Tanzimat Fermanı günümüze kadar birçok değişikliğe uğramış olsa da güncelliğini adem-i merkeziyetçi anlayıştan dolayı muhafaza ettiği de görülmektedir (Yayman, 2016: 20).

Ancak mutlak monarşinin hakim olması birçok değişikliği yavaşlatmakta ve halkın taleplerinin giderilmesi konusunda gecikmelere neden olmaktadır. Ancak 1876 y1lında ilan edilen Kanuni Esasi ile birlikte meşruti monarşiye geçiş yapılmıştır. Dolayısıyla Türk siyasal hayatının bu tarihten itibaren parlamento ile tanıştığı görülmektedir (Akçakaya ve Özdemir, 2018: 925). 1908 tarihinde ilan edilen ikinci meşrutiyet ile birlikte parlamenter sisteme yakınlaşılmıştır. 1876 Anayasası ve 1909'da yapılan bir dizi değişiklikler ile birlikte padişahın yetkileri sınırlandırılmış, yetkileri sembolik bir hal almıştır. Sınırlı yetkiler ile donatılan bir devlet başkanı durumuna gelen padişah, yürütme gücünü bakanlar kuruluna devretmiştir, bakanlar kurulu ise padişaha karşı değil yasama organına karşı sorumlu durumdadır. Bu değişiklikler sonucunda sistem parlamenter sistem görünümüne kavuşmuştur (Gözler, 2011: 21).

1920 y1lında Osmanlı Mebusan Meclisinin savaş nedeniyle işgal kuvvetleri tarafından lav edilmesinin ardından (Çilliler, 2019: 61), Türkiye Büyük Millet Meclisi'nin 23 Nisan 1920 tarihinde açılması ile yeni bir anayasa gerekliliği ortaya çıkmıştır. Oldukça kısa olmasının yanı sıra erklerin tamamının bir merkezde toplandığı meclis hükümeti sistemini öngören 1921 Anayasası ortaya çıkmıştır. Dönemin zor şartları ve savaşın etkisi ile birlikte meclis hükümeti sisteminin ve 1921 anayasasını sorgulanması anlamsızdır. Meclis hükümeti sisteminde yasama yürütme ve yargı yetkilerinin tamamı mecliste toplanır, devlet başkanı aynı zamanda meclis başkanıdır (Ağır, 2017: 185). 21 Ocak 1921 tarihinde Türkiye Büyük Millet Meclisi tarafından kabul edilerek yürürlüğe giren anayasasın birinci maddesine göre; ' 'Hakimiyet kayıtsız şartsız milletindir. İdare usulü, halkın mukadderatını bizzat ve bilfiil yönetmesi esasına dayanır "belirtildiği şekilde cumhuriyetin dolaylı ilanı anlamına gelmektedir (Aslan, 2013: 38). 1921 anayasasının bir diğer yanı ise kendinden önceki anayasa ile birlikte yürürlükte olmasıdır. Yani hem 1876 Kanun-i Esasi hem de 1921 Teşkilat-1 Esasiye birlikte uygulanmış iki anayasalı dönem olarak nitelendirilmiştir (Küçük ve Karadağ, 2013: 166).

29 Ekim 1923 tarihinde Türkiye Büyük Millet Meclisi tarafından Cumhuriyetin ilan edilmesi ile birlikte 1921 anayasasının eksikliklerinin giderilmesi gerekliliği ortaya çıkmış ve 1924 yılında Teşkilat-1 Esasiye Kanunu kabul edilerek 1921 anayasasının yerini almıştır. Kuvvetler birliği ilkesinin bazı esnekliklerle birlikte nispeten devam ediyor olması, temel hak ve özgürlükler açısından yeterli düzeye gelinememesi 1924 anayasasının temel eksiklikleri olarak öne çıkmaktadır. Dolayısıyla 1924 anayasasının meclis hükümeti sistemi ile parlamenter sistem arasında karma bir sistem öngördügü rahatlıkla söylenebilir. Bu anayasa 1961 yılına kadar varlığını muhafaza etmiştir (Tekin ve Okutan, 2012: 78).

27 Mayıs 1960 tarihine gelindiğinde Türkiye Cumhuriyeti çok partili hayata geçmiş olmasına karşın askeri darbe ile tanışmıştır. Bir grup subay sabah saatlerinde yönetime el koyduklarını belirterek darbeyi şu şekilde açıklamışlardır; '’Cumhuriyeti korumak ve kollamak, demokratik hukuk devleti esaslarını gerçekleştirip 
teminat altına alarak yeni bir anayasa ve seçim kanunu yapmak ve iktidarın, gerçekleştirilecek seçimler neticesinde teşekkül edecek yeni TBMM'ye devrini sağlamak'. Dolayısıyla darbenin meşru dayanağının Teşkilatı Esasiye Kanuni ile Türk Cumhuriyetini korumak ve kollamak Türk ordusunun görevi olduğundan Cumhuriyeti korumak ve kollamak esasına dayandırılmıştır (Küçük ve Karadağ, 2013: 175). 1960 darbesinin ardından kabul edilerek yürürlüğe giren 1961 anayasası Meclis tarafından seçilen sorumsuz ve yetkisiz bir Cumhurbaşkanı ile meclise karşı sorumlu ve yürütme konusunda yetkili bir bakanlar kurulu ile tam bir parlamenter sistem öngörmüştür. 1961 anayasası teoride öngördügünü pratikte hayata geçirememiş uygulamada kötü sonuçlar vermiştir. Bunun sebebi ise seçimlerden tek partinin iktidar olarak çıamaması ile hükümetlerin kurulamaması, kurulan hükümetlerin meclisten güvenoyu alamayarak çalışamaması, güvenoyu alarak iktidara geçen koalisyon hükümetlerinin uyumlu çalışamaması ile kısa ömürlü olması ve Cumhurbaşkanlığı seçiminin krize dönüşerek altı ay gibi sürelerde Cumhurbaşkanı seçimi yapılamaması gibi bir dizi krizler ve sorunlarla karşılaşılmıştır. Bunun sonucunda meclis işlevini yerine getirememiş, hükümetler icraat sergileyememiştir, bu durumdan 1961 anayasası sorumlu tutulmuştur (Ağır, 2017: 185). 1961 anayasasının getirdiği diğer önemli bir değişiklik ise çift meclisli yasama organını kabul ederek yürürlüğe sokmasıdır. Bu durumda yasama organı olan TBMM'nin bir kanadı Millet Meclisi iken diğer kanadı Cumhuriyet Senatosu'dur. Millet Meclisi üyeleri doğrudan halkoyu ile belirlenirken, Cumhuriyet Senatosu üyeleri doğal üye olarak nitelendirilmiş ve bir kısmı seçimle göreve gelirken bir kısmı seçim dışı yollarla belirlenmiştir (Küçük ve Karadağ, 2013: 178). Anayasa Mahkemesinin kurulması 1961 anayasasında öngörülmüş ve yarg1 yetkisi anayasal olarak Anayasa Mahkemesine bırakılmıştır (Ağır, 2017: 186).

12 Eylül 1980 sabahı radyo ve televizyon aracılığı ile Türk Silahlı Kuvvetleri'nin "Bayrak Hareketı", adı ile bir girişim gerçekleştirerek Milli Güvenlik Konseyi (MGK)'nın yönetime el koyduğunu duyurmuştur. Dönemin Genelkurmay Başkanı Orgeneral Kenan Evren, Hava Kuvvetleri Komutanı Orgeneral Tahsin Şahinkaya, Kara Kuvvetleri Komutanı Orgeneral Nurettin Ersin, Deniz Kuvvetleri Komutanı Oramiral Nejat Tümer ve Jandarma Genel Komutanı Orgeneral Sedat Celasun'dan oluşan MGK yönetime el koymuştur. MGK'nın ilk bildirisi ile ülkedeki tüm siyasi faaliyetler durdurularak kolluk kuvvetleri ile tüm kamu kurumları MGK bünyesine alındığı bildirilmiştir. Eski Deniz Kuvvetleri Komutanı Bülend Ulusu 21 Eylül 1980 itibariyle emekli edilerek onun başkanlığında bir bakanlar kurulu oluşturulmuştur (Tekin ve Okutan, 2012: 192-193). 1961 anayasasının yürürlükte olduğu dönemde ortaya çıkan siyasi krizler ve yönetim alanında oluşan boşlukların önüne geçilmek üzere yeni anayasa çalışmaları başlamıştır. MGK'nın oluşturduğu meclis tarafından hazırlanan anayasa 7 Kasım 1982 tarihinde halkoyuna sunularak, hem anayasa oylanmış hem de cumhurbaşkanı seçimi yapılmıştır. Cumhurbaşkanı sıfatını ise MGK başkanı Kenan Evren taşıyacaktır. Oylama \%92,27 evet oyuyla kabul ederek yürürlüğe girmiştir (Tekin ve Okutan, 2012: 196). 1982 anayasası yasama ve yürütme organının güçsüzleştirilmesinin sonucu olarak devlet otoritesinin zayıflık göstermesini önlemek üzere oluşturulmuştur. Bu nedenle yürütmenin güçlendirilmesini sağlamıştır. Yürütmede sembolik bir cumhurbaşkanı yerine güçlendirilmiş ve sorumsuz bir Cumhurbaşkanı olmasını sağlayarak bu durum aşılmaya çalışılmıştır.

Anayasasının 104. Maddesine göre Cumhurbaşkanının yetkileri şu şekildedir;

- Cumhurbaşkanı devletin başıdır, yürütme yetkisi Cumhurbaşkanına aittir.

- Cumhurbaşkanı devlet başkanı sıfatıyla Türkiye Cumhuriyeti'ni ve Türk Milletinin birliğini temsil eder; Anayasanın uygulanmasını, devlet organlarının düzenli ve uyumlu çalışmasını temin eder.

- Gerekli gördüğü takdirde Cumhurbaşkanı yeni yasama yılının ilk günü TBMM genel kurulunda açılış konuşması yapabilir.

- Başkomutan sıfatını taşır

- MGK’yı istediğinde toplantıya çağırabilir ve kurula başkanlık eder

- Sikıyönetim ve OHAL ilan edebilir

- Yabanci devlet temsilcilerini atar

- Yabanci devlet temsilcilerini kabul eder

- Uluslararası anlaşmaları Türkiye Cumhuriyeti adına onaylar ve yayımlar

- Başbakanı atar ve istifasını kabul eder

- Başbakanın önerisi neticesinde Bakanlar Kurulunu atar 
Türk Yönetim ve Ekonomi Araştırmaları Dergisi, 2021, C.2, S.1, ss.56-76.

- Yüksek Öğretim kurulu üyelerini belirler

- Meclisi gerekli durumlarda toplantıya çağırabilir

- Anayasa değişikliğini gerekli gördüğü takdirde referanduma götürebilir

- Anayasa Mahkemesi üyelerini seçer

- Danıştay üyelerinin 1/4' ünü belirler

- HSYK üyelerini belirler

- Askeri Yargitay üyelerini belirler

- Yargitay Cumhuriyet Başsavcısını ve vekilini atar

- Milli güvenlik politikalarını belirleyerek gerekli tedbirleri alabilir

- Türk Silahlı Kuvvetlerinin kullanımı noktasında karar verebilir

- Kanunların TBMM içtüzügü ve anayasaya şekil ve esas bakımından aykırı olması durumunda Anayasa Mahkemesine iptal davası açar.

Anayasa hazırlanırken 1961 anayasasının neden olduğu siyasi istikrarsızlığın tekrardan oluşmaması için \%10 seçim baraj1 getirilmiştir. Bu sayede seçim sisteminde nispi temsil sistemi benimsenmiştir (Demir v.d, 2017: 150). 1982 anayasası parlamenter sistem özelliklerini muhafaza etmesinin yanı sıra, Cumhurbaşkanının sembolik yetkilerden ziyade yürütmenin başı olarak nitelendirmesi ve bir başbakanı da öngörmesi ile yarı başkanlık sistemine yaklaşmıştır. Başka bir değişle rasyonelleştirilmiş parlamenterizm akımı doğrultusunda gerçekleştirilmiş klasik parlamenter sistem ile yarı başkanlık sistemi arasında kendisine özgü nitelikleri olan bir sistem görünümündedir (Kuzu, 2017: 75). Dolayısıyla 1982 anayasası 177 maddeden oluşması ve detaylı, geniş bir anayasa olması ile kazuistik bir anayasa olduğundan rahatlıkla söz edilebilir. Anayasanın siyasal uzlaşı ile değil de siyaset üstü angajman ile yapılmış olmasının sonucunda pek çok değişiklik yapılmıştır. 2017 yılına kadar geçen süre içerisinde $17 \mathrm{kez}$ değişiklik yapılarak 100'den fazla madde yeniden düzenlenmiştir. 2017 yılında yapılan referandum ile birlikte yeni hükümet modeli Cumhurbaşkanlığ 1 Hükümet Sistemi olarak benimsenmiş, değişikliğin kapsamı gereği 70 maddede düzenlemeler yapılmıştır (Çilliler, 2019: 62). Bundan öncesinde ise 2007 yılında yapılan değişiklik ile Cumhurbaşkanının halk tarafından seçilmesinin önü açılmış, parlamento içerisinden çıkmak zorunluluğu olmayan Cumhurbaşkanı yürütme yetkilerini daha aktif biçimde kullanabilir duruma gelmiştir (Ağır, 2017: 187). 2007 yılında yapılan düzenleme aynı zamanda Cumhurbaşkanının 7 yıllık görev süresini 5 yıl olarak öngörmüştür ve en fazla 2 dönem görev yapabilmesini yürürlüğe sokmuştur. Bu şarlar doğrultusunda 10 Ağustos 2014 tarihinde yapılan Cumhurbaşkanlığ1 seçimlerinde Recep Tayyip Erdoğan halkoyunun \%51,79'unu alarak Türkiye Cumhuriyeti'nin halkoyu ile seçilen ilk Cumhurbaşkanı olmuştur (Tunç, 2019: 119).

1990’lı yılların başından beri tartışılagelen başkanlık sistemi, koalisyon hükümetlerinin bitmesi, yönetimde istikrarın hakim olması, yürütmede iki başlılığın kaldırılarak işlevlik kazanması 2017 yılında yapılan 6771 sayılı kanunun 16 Nisan 2017 tarihinde yapılan halkoylaması sonucunda kabul edilerek 663 sayılı Yüksek Seçim Kurulu karar 27 Nisan 2017 tarihinde 30050 sayılı Resmi Gazetede yayınlanarak hayata geçmiş oldu (Tunç, 2019: 121). 2017 referandumu ile birlikte 18 madde sonucunda Cumhurbaşkanlığı Hükümet Sistemi Yürürlüğe girmiştir. 18 maddenin detaylı incelemesi Türk tipi başkanlık sistemi ve işleyişi başlığı altında erkler üzerinden ele alınacaktır.

\section{2. Üniter Devlet ve Başkanlık Sistemi}

Üniter devlet, tek ülke, ulus ve bunlara bağl tek siyasal örgütlenmenin hukuki biçimde düzenlendiği devlet biçimidir. Üniter devlet denildiğinde merkezi idarenin tek olduğu yapıdan bahsedilmektedir (Nalbant, 1996: 50). Üniter kelime anlamı olarak tek, bütün, yekpare anlamına gelmektedir. Dolayısıyla üniter devlet denildiğinde bütün ülkede tek bir devletin olduğu ve bu devletin egemenliği elinde bulundurarak başka birimle paylaşmadığı siyasi sistemin merkeziyetçi olduğundan bahsedilmektedir. Bütün kararların merkezden yani başkentten alındığı, alınan kararların merkezin kontrol ve denetiminde taşrada uygulandığı anlaşılmaktadır (Yayla, 2015: 66). Üniter devlette tek bir otoriter yapının ve merkezi hükümetin olduğu devlet biçimidir. 
Federal devlette olduğu gibi güç ve otorite farklı birimlerle paylaşılmaz (Dağ, 2016: 376). Üniter ve Federeal devlet arasındaki farkı şu şekilde anlatmak mümkündür;

Tablo 1: Üniter ve Federal Devlet Farklılıkları ${ }^{2}$

\begin{tabular}{|c|c|c|}
\hline & Üniter & Federal \\
\hline Devlet & Tek Devlet & $\begin{array}{l}\text { Bir Federal Devlet ve federe } \\
\text { devletler var }\end{array}$ \\
\hline Hukuk Sistemi & Tek bir hukuk sistemi hakim & $\begin{array}{l}\text { Bir federal hukuk sistemi var, } \\
\text { federe devletlerin birden çok } \\
\text { hukuk düzenleri var }\end{array}$ \\
\hline Erkler & $\begin{array}{l}\text { Yasama, yürütme ve yarg1 } \\
\text { organları tektir. }\end{array}$ & $\begin{array}{l}\text { Federal yasama, yürütme ve yargı } \\
\text { organı var. Her federe devletin } \\
\text { kendi yasama, yürütme, yargı } \\
\text { organı var. }\end{array}$ \\
\hline Yetki Paylaşımı & $\begin{array}{lcc}\text { Merkezi yönetim ile } & \text { yerel } \\
\text { yönetimler arasında } & \text { yetki } \\
\text { paylaşımı kanunla yapı1lır. } & \end{array}$ & $\begin{array}{l}\text { Federal devlet ile federe devletler } \\
\text { arasındaki yetki paylaşımı } \\
\text { kendilerini bağlayıcı olan anayasa } \\
\text { ile yapılır }\end{array}$ \\
\hline
\end{tabular}

Türkiye Cumhuriyeti'nin kuruluşundan bu yana üniter devlet yapısını benimsediğini görmekteyiz. Bu durumun en önemli nedeni ise Osmanlı döneminde çok geniş topraklara sahip olunması ve federal yapının Osmanlı'nın dağılmasında önemli bir etken olmasıdır. Dolayısıyla geçmişte kaybedilen toprakların oluşturduğu hayal kırıklığı ile merkezi yönetim odaklı kurulan ulus devletin üniter yapıda olması sonucu ortaya çıkmıştır. Kuruluşundan günümüze kadar bölünmemiş erkleri üniter devlet niteliğini muhafaza eden Türkiye Cumhuriyeti merkezi iktidarı ve etki gücünü tek merkezde toplamıştır. İller başka bir değişle yerel yönetimler merkezin atadığ dikey olarak bütünleştirilmiş bir görünüme sahiptir ve bu yönüyle federal yapıdan oldukça uzaktır (Çilliler, 2019: 58).

Türkiye'de başkanlık sisteminin tartışılmaya başlandığı dönemlerden beri federal yapı tartışıla gelmiştir. Bunun nedeni ise bir önceki paragrafta belirtildiği gibi Osmanlı Devleti'nin çok geniş bir coğrafyaya sahip olmasına karşın elinde kalan toprakların çok az olmasıdır. Dolayısıyla Türkiye'de uygulanan Cumhurbaşkanlığı Hükümet Sisteminin kuruluşundan günümüze kadar var olan üniter devlet yapısına uygun biçimde devam ettirildiği görülmektedir (Kuzu, 2017: 138). Türkiye'nin üniter sistemi devam ettirmesinde ki bir diğer önemli nokta ise güvenlik ve terör sorunlarından kaynaklıdır. Federal bir sistemin uygulanması ile ülkenin bütünlüğü ve üniter yapısının tehlikeye girmesi durumu söz konusudur. Dolayısıyla bu düşünceden kuruluşundan günümüze kadar uzak durulmuş, üniter devlet yapısı ile birlikte, erklerin tek olması düşüncesi benimsenmiştir (Güzel, 2013: 478).

\subsection{Seçim Sistemi}

Türkiye Cumhuriyeti'nde seçimler yasama ve yürütme organı için ayrı ama aynı gün yapılmaktadır. Milletvekili seçimlerinde ülke barajlı D'Hondt seçim sistemi kullanılmaktadır. Bu sisteme göre \%10 seçim barajını geçen partiler parlamentoda temsilci bulundurabilir. Ancak bu durumda ittifak yasasının yürürlüğe girmesi ile birlikte değişmiştir. İttifak yasasına göre, seçim ittifakı içerisinde olan partiler ortak adayları ile

\footnotetext{
${ }^{2}$ Tablo araştırmacı tarafından geliştirilmiştir.
} 
seçime girerler (7102. Kanun 10. Madde, resmigazete.gov.tr). İttifak durumu Cumhurbaşkanlığı Hükümet Sisteminin yürürlüğe girmesinden önce yasal değildi. Ancak yeni hükümet sistemi ile birlikte seçim yasasından yapılan bir dizi değişikliğin ardından yasal hale getirilerek yürürlüğe girmiştir (Çilliler, 2019: 136). İttifakın elde edeceği temsilci sayısının hesaplanmasında, ittifak partilerinin toplam oyları esas alınarak yapılır. İttifak oyu ile ilk olarak ittifakın toplam milletvekili hesaplanmaktadır, daha sonra bu sayı ittifak partilerine dağılmaktadır. Seçimlerde ittifak partilerinin herhangi birisine oy verilebileceği gibi ittifaka da oy verilebilir, bu oylar ittifaka yazılır. Ancak ittifak partilerinin aldıkları oy oranında bölünür (Çirkin, 2019: 440). Ortaya çıkan oy nispetinde seçime tek başına giren siyasi partiler ve ittifak partileri parlamentoda temsilci bulundurur. İttifak yasasının yürürlüğe girmesi ile birlikte \%10 seçim barajı olmasına karşın ittifaklar sayesinde birçok parti parlamentoda temsilci bulundurma firsatı yakalamıştır. Seçim sisteminin bu şekilde olmasına karşın anayasada seçim sistemi isminden söz edilmemektedir.

Cumhurbaşkanının görev süresi 5 yıldır. Aynı şekilde parlamento üyelerinin görev süresi de 5 yıldır. Her 5 yılda bir düzenli yapılan seçimlerle Cumhurbaşkanı ve TBMM üyeleri belirlenerek görevlerine başlar. Yürütme ve yasama organının seçimleri ayrı olmasına karşın aynı gün yapılır. Temsilde adalet ilkesi gereği seçime katılan partiler ittifaklı olsun olmasın ortaya çıkan sonuç nispetinde parlamentoda temsil hakkını elde eder (Türk, 2006: 78). 6271 sayılı kanun ile Cumhurbaşkanlığı seçimlerinin nasıl yapılacağı belirlenmiştir. Bu kanuna göre TBMM ve Cumhurbaşkanı her 5 yılda bir aynı günde yapılır, bir kişi en fazla iki defa Cumhurbaşkanı olabilir, ancak ikinci döneminde TBMM tarafindan seçimlerin yenilenmesine karar verilmesi durumunda Cumhurbaşkanı bir defa daha aday olabilmektedir (6271 Kanun Madde 3, ysk.gov.tr). Cumhurbaşkanı ve TBMM'nin görev sürelerinin bitiminden bir önceki hafta Pazar günü seçim günüi olarak belirlenir (Madde 4). Seçimler genel oy ile yapılacak biçimde, geçerli oyların salt çoğunluğunu alan aday Cumhurbaşkanı olarak seçilir. Ancak Cumhurbaşkanlığı seçiminin ikinci tura kalması durumunda seçimden sonrası pazar günü ikinci seçim gerçekleştirilir (Madde 4). Cumhurbaşkanı adayı olabilmek için çeşitli yöntemler bulunmaktadır. Bunlar; siyasi parti grupları tarafından, yüz bin seçmen tarafından aday gösterilmektir (Madde 8). Seçimlerde propaganda dönemi aday listelerinin kesinleştiği gün itibariyle başlar, seçim gününden önceki gün saat 18:00 itibariyle sona erdirilir (Madde 13).

Cumhurbaşkanlığı seçimlerinin tek veya iki turlu olması adayların düşük bir oranı ile seçilmesinin ve dolayısıyla seçilecek adayın meşruiyetinin sorgulanmasını engellemek üzere geliştirilmiştir. Ancak tek turlu seçim durumunda meşruiyet sorgulanması problemi ile karşı karşıya kalınmamasını isteyen karar alıcılar, iki turlu sistemi benimsemişlerdir. Dolayısıyla ilk turda salt çoğunluğunun sağlanamaması durumunda ikinci tura adaylardan en fazla oyu alan ilk iki kişi kalmaktadır. Bu durum ise kalan adaylar üzerinde siyasal eğilimlerin birleşerek uzlaşmasını mümkün kılmaktadır. Uzlaşmanın ise kutuplaşma ve parçalanmanın önüne geçilmesini sağlamaktadır (Gülener ve Miş, 2017: 61). Cumhurbaşkanı adayının partili veya partisiz olmasına bakılmaz. Önceki dönemlerde Cumhurbaşkanı seçilen kişinin partisinden istifa ederek göreve başlaması gerekmesine karşın Cumhurbaşkanlığı Hükümet Sistemi ile birlikte bu durum ortadan kalkmıştır (Miş ve Duran, 2017: 44).

ABD başkanlık sistemine göre Cumhurbaşkanlığı Hükümet Sisteminin farklılıklarından biri seçimlerin tek yasama ve yürütme organı için yapılmasıdır. Dolayısıyla üniter yapıda olan Türkiye Cumhuriyet'i kendine özgü bir seçim sistemi kullanmaktadır. Seçimleri yürütmek, oy pusulalarını basmak, seçim sonuçlarını açıklamakla yetkili kurum YSK'dır. YSK'nın görev ve yetkileri 7062 ve 298 sayılı kanunlarla belirleniştir (ysk.gov.tr)

\subsection{Siyasal Partiler}

1946 yılına kadar Türkiye'de tek parti iktidarı hakim olmuştur. 1946 yılında ise CHP iktidarının ciddi eleştirilere maruz kalması sonucunda çok partili hayata geçilmiştir. 1946 yılında yapılan ilk çok partili seçimleri CHP önde tamamlamasına karşı 1950 genel seçimlerinde iktidarı Demokrat Partiye devretmiştir (Aslan, 2013: 87). Dolayısıyla tek parti iktidarının 23 yıl sürmesinin ardından çok partili hayata geçilmiştir. 27 Mayıs 1960 tarihine gelindiğinde ordu darbe ile yönetime el koymuştur. Türk siyasal hayatı ilk defa darbeyle bu tarihte tanışmışır. Dönemin Cumhurbaşkanı Celal Bayar ve Başbakanı Adnan Menderes başta olmak üzere pek çok siyasi tutuklanmıştır. 29 Eylül 1960 tarihinde ise DP kapatılmışıı. Aynı dönemde meclis de feshedilmiştir. Dolayısıyla her türlü siyasi faaliyetin askıya alındığını söylemek mümkündür. Bu dönemde ordu tarafindan kurulan Milli Birlik Komitesi tarafından tüm yönetim yetkileri ile donatılmıştır. Yassıada'da yapılan yargılamalar sonucunda Başbakan Menderes, Dönemin bakanlarından Fatih Rüştü Zorlu ve Hasan Polatkan idam cezası alarak infaz edilmiştir (Tuncel, 2013: 236).

15 Ekim 1961 tarihinde milletvekili genel seçimleri yapılarak CHP \%36,7 oy ile 173 milletvekili, Adalet Partisi \%34,8 oy oranı ile 158 milletvekili, Cumhuriyetçi Köylü Millet Partisi \%13,9 oy ile 54 
milletvekili, Yeni Türkiye Partisi \%13,7 oy oranı ile 65 milletvekili elde etmiştir. Ancak Milli Birlik Komitesi, kapatılan Demokrat Partinin varisleri olarak kabul edilen Adalet ve Yeni Türkiye Partilerinin aldığ oy oranından rahatsız olarak sivil yönetime geçilmemesi kararını almışlardır. Sivil yönetime geçiş için formüller arayan komite üyeleri Cemal Gürsel başkanlığında siyasi parti liderleri ile bir protokol imzalanması ile süreci sonlandırmışlardır Sivil yönetimin ilk hükümeti Adalet ve Cumhuriyet Halk Partilerinin koalisyonu ile kurulmuştur. Ancak bu hükümet 1 yıl gibi kısa bir süre çalışabilmiştir. Ardından kurulan üç hükümette kısa süreli koalisyonlardan oluşmuştur. 10 Ekim 1965 tarihinde yapılan seçimlerle Adalet Partisi \%52,8 oyla 240 milletvekili elde ederek tek başına iktidar olmuştur, koalisyon dönemine son vermiştir. Süleyman Demirel liderliğindeki Adalet Partisi tek başına iktidara gelerek kendisinden önceki koalisyon dönemlerinde yaşanan siyasal istikrarsılılı̆ 1 sona erdirileceği düşünülmüsstür. Ancak dünyada yaşanan toplumsal huzursuzluklardan özellikle 1968 senesinde başlayan öğrenci hareketlilikleri ve ideolojik ayrışmalar neticesinde 1970 sonrasında özellikle kutuplaşacak gençler yetişmeye başlamıştır (Tekin ve Okutan, 2012: 160).

1969'da yapılan seçimlerde Adalet Partisi'nin 1965 seçimine göre oy oranında düşüş görülmüştür. Ancak seçim sisteminin değişmesinin de etkisiyle meclisteki temsilci sayısı artmıştır. Dolayısıyla tek başına yeniden iktidar olmuştur. İki seçim dönemi tek parti iktidarı olması ile birlikte siyasi istikrar kısmen sağlanmış oldu. Şubat 1970'de mecliste yapılan bütçe görüşmelerine DP milletvekillerinin red oyu vermesi Adalet Partisi’nin ikinci döneminin bitmesini sağlamıştır. Sağ-sol çekişmelerinin yaşanması ile birlikte öğrenci hareketleri, işçi mitingleri ve ABD karşıtlığı artmıştır. 12 Mart 1971 tarihinde ordu yayınladığı muhtıra ile Demirel'i başbakanlıktan uzaklaştırmış, Adalet Partisinin de iktidardan düşmesini sağlamıştır. Muhtıra ile anayasa askıya alınıp meclis feshedilmiştir. Ancak 1960 darbesinde olduğu gibi siyasi partiler kapatılmamıştır. Muhtıranın ardından teknokratlardan oluşan bir hükümet kurulması isteği ile CHP milletvekili Nihat Erim başkanlığında bir hükümet kurulmuştur. 1973 yılında yapılan seçimlerle birlikte uzun bir süre siyasi istikrarsızlığın devam edeceği bir tablo ortaya çıkmıştır. Dönemin CHP genel başkanı Bülent Ecevit ile ortanın solu olarak kendini konumlandıran parti tek başına iktidar olabilecek çoğunluğu sağlayamayarak koalisyon kurma yoluna girmiştir (Tuncel, 2013: 240).

1970 ve 1980 arası dönemde kurulan koalisyon hükümetleri nedeni ile siyasi istikrar sağlanamamış, istikrarmış ortamda siyasi gerilimler artarak devam etmiştir. Bu durumun sonucunda 12 Eylül 1980 tarihinde ordu yönetime el koyarak siyasi faaliyetleri ve anayasayı rafa kaldırmıştır. Darbenin en önemli gerekçeleri Cumhurbaşkanlığı seçimlerinin uzun bir süre boyunca yapılamaması, ülkenin içerisinde olduğu ekonomik buhrandır. 12 Eylül sabahında radyolardan yapılan duyuru ile TSK'nın 'Bayrak Harekatı" adı altında bir girişim gerçekleştirdiği ve MGK adıyla yönetime el koyduğunu duyurmuştur. Bu tarihe kadar Türkiye'de önemli faaliyetler yürüten ve seçmenden takdir alan siyasi partiler; Adalet Partisi, Cumhuriyet Halk Partisi, Milli Selamet Partisi, Türkiye İşçi Partisi, Cumhuriyetçi Güven Partisi, Milliyetçi Hareket Partisi, Cumhuriyetçi Köylü Millet Partisi, Millet Partisi, Yeni Türkiye Partisi, Birlik Partisi'dir. Bu darbe sonrasında yeni anayasa hazırlanarak yürürlüğe girmiştir. MGK'nın 24 Nisan 1983 tarihli resmi gazetede yayınlanan kararı ile siyasi partilerin yeniden kurulmasına izin verilmiştir. MGK denetiminde yapılan 1983 seçimlerine Anavatan Partisi, Halkçı Parti, Milliyetçi Demokrasi Partisi'nin seçimlere katılmasına izin verilmiştir. Anavatan Partisi seçimlerde \%45 oy oranı ile 212 milletvekili elde ederek tek başına iktidar olmuştur. Genel seçimi takip eden yerel seçimlerde Anavatan partisi bir zafer daha elde etmiş̧tir (Tekin, Okutan, 2012: 200).

1980'de darbe ile birlikte duran siyasi faaliyetler, 1983 seçimlerinin yapılması ile birlikte yeniden başlamıştır. Bu dönemde dünyada olduğu gibi Türkiye'de de yeni-sağ kavramı türemiş, sağ yönelimli partiler hem yüksek oy oranlarına sahip olmuş hem de yönetimi uzun süre ellerinde tutmuşlardır. 1980 sonrası dönem için İngiltere'de Thatcher, Amerika'da Reagen, Türkiye'de ise ANAP ve lideri Özal yeni-sağ politikalarının uygulayıcıs1 olmuştur (Safi, 2007: 263). 1980 sonrası dönemde aktif rol oynayan siyasi partiler; Anavatan Partisi, Sosyal Demokrat Halkçı Parti, Cumhuriyet Halk Partisi, Refah Partisi, Doğru Yol Partisi, Milliyetçi Çalışma Partisi, Demokratik Sol Partisi'dir. Bu dönemde özellikle Özal'ın Cumhurbaşkanlığına giden sürecinde yürüttügü politikalar ile Türkiye'nin önünü açtığından kolaylıkla bahsedilebilir. SSCB'nin dağılması ile birlikte ortaya çıkan bağımsız devletler ile kurulacak iyi ilişkiler, hem Türkiye'nin Pazar payını büyütmüş, hem de ekonomik büyümeyi sağlamıştır (Tekin ve Okutan, 2012: 212). Bu dönem özellikle 2002 yılına kadar birçok koalisyon hükümeti, ekonomik krizler, siyasi istikrarın olmaması, koalisyon hükümetlerinin uzun süre dayanamaması gibi nedenler ile tek parti iktidarından bahsedilemez. Ayrıca Laikliğe aykırı faaliyetleri gerekçesi ile Anayasa Mahkemesi tarafindan Refah Partisi kapatılmış, lideri Erbakan başta olmak üzere bazı partililere beş yıl siyaset yasağı getirilerek siyaset arenasından düşmesi sağlanmıştır. Ancak ardılı olan ve Recai Kutan tarafindan 1997 yılında kurulan Fazilet Partisi adı le tekrar kurulmuştur. Kurulan parti içerisinde yenilikçi ve gelenekçi kanatların rekabeti 1999 seçimleri ardından daha da kızışarak, 2000 yılında yapılan parti kongresinde gelenekçilerin adayı ve mevcut genel başkan Recai Kutan'ın karşısına yenilikçilerin adayı Abdullah Gül 
çıkmıştır, oldukça sert bir ortamda gerçekleşen kongrede Kutan genel başkanlık koltuğunu korumuştur. Ancak 2001 yılında Fazilet Partisi laikliği ihlal ettiği gerekçesi ile kapatılmıştır. Milli Görüş harekatı adı altında bu iki partiyi oluşturan kesim 2001 yılında Saadet Partisini kurmuştur. Saadet Partisi gelenekçi kanadı çatısı altında toplarken, yenilikçi kanat ise Adalet ve Kalkınma Partisi’ni kurarak Recep Tayyip Erdoğan liderliğinde yoluna devam etmiştir (Tuncel, 2013: 245).

14 Kasım 2001 tarihinde "'Erdemliler Hareketi "adiyla siyaset sahnesine giren AK Parti kuruluşundan kısa bir süre sonra 3 Kasım 2002 tarihinde tek başına iktidara gelmiştir. Bu seçimde önceki parlamentoların aksine iki parti mecliste temsilci bulundurmuştur (aa.com.tr). 18 yıl aralıksız iktidarda kalan AK Parti yönetimde istikrar olgusunun yakalanmasını sağlamıştır. 2002 genel seçimlerinde \%34 oy oranı ile 365 milletvekili elde ederek Cumhuriyet tarihinin Demokrat Parti'den sonra en güçlü siyasal grubu haline gelmiştir. 58. Cumhuriyet Hükümeti Abdullah Gül başkanlığında kuruldu. YSK'nın Siirt seçimlerini yenileme kararı ile Erdoğan'a meclise girme imkanı doğmuş, 9 Mart 2003 tarihinde yapılan seçimler ile Siirt'ten milletvekili seçilen Erdoğan Gül'ün 11 Mart'ta istifa etmesiyle 59. Hükümeti kurarak başbakan olmuştur (Safi, 2007: 295). Bu dönemin ardından 18 yıl aralıksız iktidarda kalan AK Parti birçok alanda revizyona gitmiştir. Bunlardan en önemlisi ise Parlamenter sistemden Cumhurbaşkanlığ Hükümet Sistemine geçiş olmuştur. Yargitay kayıtlarına göre Türkiye'de aktif 89 siyasi parti bulunmaktadır (yargitaycb.gov.tr). Bunların bir kısmı seçimlere girmemektedir. Mecliste temsilcileri olanlar1;

Tablo.2. Mecliste Temsilcisi Olan Siyasi Partiler

\begin{tabular}{|c|c|c|}
\hline Parti Adı & Kısa Adı & Kuruluş Tarihi \\
\hline Demokrat Parti & DP & 23.06.1983 \\
\hline Milliyetçi Hareket Partisi & MHP & 07.07 .1983 \\
\hline Cumhuriyet Halk Partisi & $\mathrm{CHP}$ & 09.09.1992 \\
\hline Büyük Birlik Partisi & BBP & 29.01.1993 \\
\hline Saadet Partisi & Saadet & 20.07.2001 \\
\hline Adalet ve Kalkınma Partisi & AK Parti & 14.08.2001 \\
\hline Demokratik Bölgeler Partisi & DBP & 02.05 .2008 \\
\hline Halkların Demokratik Partisi & HDP & 15.10 .2012 \\
\hline İYİ Parti & İYİ Parti & 25.10 .2017 \\
\hline Türkiye İşçi Partisi & TİP & 07.11 .2017 \\
\hline Demokrasi ve Atılım Partisi & DEVA & 09.03 .2020 \\
\hline
\end{tabular}

Kaynak: TBMM (https://www.tbmm.gov.tr/develop/owa/milletvekillerimiz_sd.dagilim).

14 Ağustos 2001 tarihinde Adalet ve Kalkınma Partisinin kurulması ile birlikte Demokrat Partiden bu yana Türk Siyasal Hayatında yönetimde istikrar yakalanmıştır. Halktan aldığı ciddi destekle 18 yıl aralıksız iktidarda kalan AK Parti kendisini muhafazakar demokrat olarak tanımlamaktadır. Dolayısıyla kendisini merkez sağa konumlandırmaktadır (Kiriş, 2010: 124). Milli Görüş Harekatı içerisinden çıkan AK Parti dindarmuhafazakar kitleyi bir arada toplamayı başarmıştır (Küçükyılmaz, 2011: 180). 2002 seçimlerinde mecliste AK Parti ve CHP'den oluşan çift partili bir yapı ortaya çıkması damga vurmuştur. 2002'den 2015'e kadar AK 
Parti'nin seçimleri tek başına kazanması bazı siyaset bilimciler tarafından hakim tek parti sistemine doğru Türkiye'nin evrildiği düşüncesini ortaya çıkarmıştır. Bu durum 2017 yılında Cumhurbaşkanlığ 1 Hükümet Sistemine geçilmesi ile birlikte bu düşünce çürütülmüştür. 2017'den itibaren 1lımlı çok kutuplu parti sisteminin olduğunu söylemek mümkündür (Çilliler, 2019: 106). ABD ve Türkiye Başkanlık sistemi uygulamalarında parti sistemlerinin ve sayılarının farklılığı da dikkat çekmektedir. Hakim iki parti anlayışının hakim olduğu ABD'ye karşın Türkiye'de çok fazla parti bulunmaktadır.

Tablo.3. Mecliste Grubu Olan Partilerin Söylem ve Politikaları

\begin{tabular}{|c|c|c|c|c|}
\hline Partiler & AK PARTI & CHP & MHP & HDP \\
\hline $\begin{array}{l}\text { Din/Laiklik } \\
\text { Politikaları }\end{array}$ & \begin{tabular}{lr} 
Din & Düşmanlığı \\
Olmayan & \multicolumn{2}{c}{ Laiklik } \\
Anlayış1, & Dinin En En \\
Büyük & Kurumlardan \\
Olması &
\end{tabular} & $\begin{array}{l}\text { Vurgulu Laiklik Anlayışı, } \\
\text { Dinin } \\
\text { Siyasallaştırılmaması }\end{array}$ & 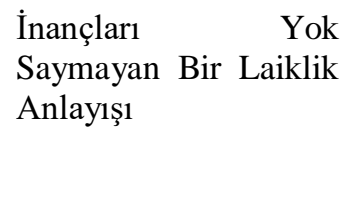 & $\begin{array}{lr}\text { Devletin } & \text { Otoriter } \\
\text { Laiklik Anlayışı, Din } \\
\text { ve İbadetin İnanç } \\
\text { Gruplarına } \\
\text { Bırakılması }\end{array}$ \\
\hline $\begin{array}{l}\text { Etnik } \\
\text { zhepsel } \\
\text { tikalar }\end{array}$ & $\begin{array}{l}\text { Dindarlarının Rencide } \\
\text { Edilmemesi, Etnisiten- } \\
\text { in İstismar } \\
\text { Edilmemesi }\end{array}$ & $\begin{array}{l}\text { Alevilere Yönelik Haklar, } \\
\text { Etnisite Bakımından } \\
\text { Asimilasyon Yerine Ente- } \\
\text { grasyon }\end{array}$ & Milli Kimlik & $\begin{array}{lr}\text { Kürt } & \text { Sorununa } \\
\text { Çözü̈m, } & \text { Çok } \\
\text { Külttürlülük, } & \text { Ana } \\
\text { Dilde Eğitim, Alevi } \\
\text { vb. Yönelik Halklar }\end{array}$ \\
\hline $\begin{array}{l}\text { Ekonomi } \\
\text { tikaları }\end{array}$ & $\begin{array}{l}\text { Piyasa Ekonomisi ve } \\
\text { Sosyal Refah }\end{array}$ & Sosyal Piyasa Ekonomisi & $\begin{array}{l}\text { Piyasac1 } \\
\text { Ekonomi }\end{array}$ & $\begin{array}{l}\text { Ulusal ve Küresel } \\
\text { Ekonomi Dengesi ile } \\
\text { Kamu ve Özel Sektör } \\
\text { Birlikteliği }\end{array}$ \\
\hline $\begin{array}{l}\text { Belirgin } \\
\text { Söylemleri }\end{array}$ & $\begin{array}{l}\text { Geleneği Önemseyen } \\
\text { Modernlik }\end{array}$ & Altı Ok, Anadolu Solu & $\begin{array}{l}\text { Türk Toplumculuğu } \\
\text { ve Milliyetçilik }\end{array}$ & \\
\hline $\begin{array}{l}\text { Açılkladıkları } \\
\text { Konumları }\end{array}$ & Muhafazakar Demokrat & Sosyal Demokrasi & Milliyetçilik & Eşitlikçi Sol \\
\hline
\end{tabular}

Kaynak: Kiriş, 2010: 130.

Tablo 3'de görüldüğü üzere Türkiye Cumhuriyeti'nde siyasi partilerde ideolojik ayrilıklar mevcuttur. Bundan dolayı merkez konumunu elde etmek üzere siyasi partiler sürekli rekabet içerisindedir. AK Parti’nin milli görüş hareketinden ayrılması ve Demokrat Parti, Anavatan Partisi gibi merkez sağ partilerin yerine kendini konumlandırması uzun süre iktidarda kalmasını sağlamıştır. Sol tarafta ise merkez bir partinin varlığından bahsetmek mümkün değildir. CHP her ne kadar merkez sol olarak kendisini tanımlasa da solun bölünmüş olması iktidar şansını azaltmıştır. MHP'nin milliyetçi söylemleri ile 1983 yılından bu yana koruduğu bir siyasi kimliği bulunmaktadır. Ancak iktidar şansı yakalayamamış, să̆ partiler ile koalisyon ve ittifak içerisinde olmuştur. HDP ise BDP'nin kapatılması ardından kurulması ile BDP'nin söylemlerini benimsemiş ve varisi olarak siyasi hayatta yerini almıştır. ABD'nin aksine çok partili yapı olması ve partilerin ideolojik ayrılıklarının olması Türkiye Cumhuriyeti siyasal sisteminin en büyük farklılığıdır. Ayrıca ABD'de olduğunun aksine parti liderinin parti politikaları alanında çok ciddi etkinliği bulunmaktadır.

\section{TÜRK TIPİ BAŞKANLIK SISTEMI VE ISSLEYIŞ̧i}

2007 yllında Cumhurbaşkanın doğrudan halkoyu ile seçilmesi gündeme gelmiştir. Bunun sebebi ise literatüre 367 krizi olarak geçen olayın gerçekleşmesidir. Cumhurbaşkanının meclis içerisinden 367 yeter sayısı ile seçilmesi gerekli olmasına karşın bu sayının uzun bir süre sağlanamaması dolayısıyla Cumhurbaşkanlığı seçimleri gerçekleştirilememiştir. Yeni sistemin temellerinin atıldı̆̆ 21 Ekim 2007 tarihinde Cumhurbaşkanının 
halk tarafindan seçilmesine dair anayasa değişikliği referanduma sunulmuş, \%69'luk bir evet oyuyla yürürlüğe girmiştir (Tunç vd, 2018: 68). 2007 referandumu neticesinde Cumhurbaşkanının görev ve yetkilerinde bir artış olmamıştır. Bunun nedeni ise Cumhurbaşkanının görev ve yetkilerinin belirlendiği anayasanın 104. Maddesinde bir değişiklik yapılmamış olmasıdır (Akıncı, 2019: 18).

16 Haziran 2017 tarihinde yapılan anayasa değişikliği referandumu ile birlikte Cumhurbaşkanlığı Hükümet Sistemine geçilmiş oldu (Akınc1, 2020: 18). 24 Haziran 2018 tarihinde yapılan Cumhurbaşkanlığı ve Milletvekili seçimleri ile birlikte Türkiye yeni hükümet sistemini uygulamaya geçirmiş oldu. Süreç sonrasındaki köklü revizyonlar ise AK Parti ve MHP'nin Cumhurbaşkanı olarak seçime giren ve ilk turda \%52,9 gibi bir oy oranı alarak Cumhurbaşkanı seçilen Recep Tayyip Erdoğan'ın kanun hükmünde kararnameleri, kararları ve genelgeleri ile hayata geçirilmiştir (Turan, 2018: 43). Kırk yılı aşkın süredir devam eden başkanlık sistemi tartışmaları bu şekilde sona ermiş oldu. Dolayısıyla Türk Siyasal sisteminin değişimi gerçekleşmiş oldu. Referandumda kabul edilerek yürürlüğe giren 6771 sayılı kanun maddeleri (6771 Sayılı Kanun).

- $\quad$ Yargı bağımsızlığına ek olarak tarafsızlığı ilkesi anayasanın 9. Maddesine eklendi

- $\quad$ Anayasanın 76. Maddesinde yapılan değişiklik ile Milletvekili sayısı nüfus artışları gözetilerek 550'den 600'e çıkarıldı Milletvekili seçilme yaşı 25'ten 18'e indirildi. Milletvekili seçilebilmek için gerekli olan niteliklerden askerliği yapmak şartı kaldırıldı.

- $\quad$ Anayasanın 77. Maddesinde yapılan değişikliğe göre yasama ve yürütme organlarının seçimlerinin 5 yılda bir aynı gün yapılması kararlaştırıldı. Cumhurbaşkanlığı seçim sistemi için 2007 yılında yapılan referandum ile kabul edilen iki turlu seçim sistemi uygulanması devam ettirildi.

- $\quad$ Cumhurbaşkanlığı Hükümet Sistemine uygun olarak TBMM'nin görev ve sorumluluklarının yer aldığı anayasanın 87. Maddesinde değişiklikler yapılmıştır. Yasamanın yürütmesi ile ilgili ibare kaldırılarak kuvvetler ayrılı̆̆ı ilkesinin işleyişine dikkat çekilmiştir. Ayrıca meclisin KHK çıkarma izni verme yetkisi sona erdirilmiştir. Cumhurbaşkanının yürütme ilgili alanlarda yasa değişikliği teklifi veremediğinden ' 'kanun tasarısı" kavramı anayasadan çıkarıldı.

- $\quad$ TBMM'nin yürütmeyi denetleme araçlarından birisi olan meclis araştırması, genel görüşme ve meclis soruşturmaları korunmuş, soru ile denetleme ise yazılı olarak devam ettirilmesi kararlaştırılmıştır. Gensoru uygulaması ise yeni sisteme uygun olarak kaldırıldı.

- $\quad$ Cumhurbaşkanlığı adaylığ1 ve seçim usulü düzenlendi anayasanın 101 ve 102. Maddeleri birleştirilerek Cumhurbaşkanı seçilen kişinin partisi ile ilişiği kesilir ibaresi kaldırılarak Cumhurbaşkanının partili olabilmesi ile ilgili engel kaldırılmış oldu. Cumhurbaşkanının görev süresi 5 yıl ve en fazla iki dönem olarak düzenlendi. Yürütme üyesinin aynı zamanda yasama üyesi olamayacağı şartı getirildi. Cumhurbaşkanının 40 yaşını doldurmuş, yükseköğretim mezunu, milletvekili yeterliliğine sahip Türk vatandaşlarının Cumhurbaşkanı adayı olabilmesi şartı ise devam ettirildi. Son genel seçimlerde $\% 5$ ve üzeri oy almış partiler veya yüz bin seçmenin Cumhurbaşkanı adayı gösterebileceği şartı getirildi Seçimler ise iki turlu olmak üzere ilk turda \%50 den fazla oy alanın seçileceği biçiminde düzenlendi. İlk turda salt çoğunluk sağlanamaması durumunda en fazla oyu alan iki aday arasında seçimlerden sonraki Pazar günü tekrar edilmesine karar verildi

- $\quad$ Anayasanın 104. Maddesinde belirtilen Cumhurbaşkanı devletin başıdır ifadesine ek olarak yürütmenin de başıdır ifadesi eklenmiştir. Bakanların ve cumhurbaşkanı yardımcılarının cumhurbaşkanı tarafından atanacağ Cumhurbaşkanının kararname çıkarma yetkisi ise temel haklar, kişi hakları, siyasi haklar alanlarında çıkarılamaz, kanunda açıkça düzenlenmiş alanlarda Cumhurbaşkanlığı kararnamesi düzenlenemez dolayısıyla Cumhurbaşkanlığı kararnamesi ile kanunlar arasında farklı hüküm bulunması durumunda kanunlar uygulanır. Meclisin aynı konuda kanun çıkarması durumunda ise Cumhurbaşkanlığı kararnamesi geçersiz olacağ biçiminde düzenlendi. Kanun tasarısı yetkisinin Cumhurbaşkanından alınması ile birlikte cumhurbaşkanının bağlayıc1 olmayan mesaj yoluyla yasa değişikliğinde bulunabilmesi yürürlüğe girdi. Üst düzey kamu görevlilerinin atanması veya görevden alınmasına yönelik usul ve kararların Cumhurbaşkanlığı kararnamesi ile yapılması kararı yürürlüğe girerek atama ve görevden alma yetkisi Cumhurbaşkanına bırakıldı.

- Anayasanın 105. Maddesinde yapılan değişiklik ile Cumhurbaşkanının cezai sorumluluk kazanması sağlandı. Görevi ile ilgili, veya başka konularda eylemlerinden sorumlu olduğu, meclis tarafindan suçlanması dahilinde Yüce Divan'da yargılanmasının önü açıldı. Hakkında meclis salt veya beşte üç çoğunluk ile soruşturma açılan Cumhurbaşkanının seçim kararı alamaması kuralı getirildi. Yüce Divan'da hüküm yiyen bir Cumhurbaşkanının görev süresinin sona erdirilmesi yürürlüğe girdi. 
- Anayasanın 106. Maddesi ile yapılan değişiklik gereği Cumhurbaşkanı yardımcılarının sayısını belirleme ve atama yetkisi Cumhurbaşkanına bırakılmışır. Kendisine vekalet edecek Cumhurbaşkanı yardımcısını belirlemek, bakanları atamak da Cumhurbaşkanının yetkisi dahilindedir. Bakanların ve Cumhurbaşkanı yardımcılarının yasama üyesi olması durumunda vekilliklerinin sona erdirileceği hükmü yürürlüğe girdi.

- Yürütme üyelerinin yasamaya karşı sorumlulukları bulunmamaktadır. Yürütme üyeleri sadece Cumhurbaşkanına karşı sorumludur. Dolayısıyla kuvvetler ayrılığı ilkesi keskinleştirilmiştir. Yürütme üyelerinin cezai sorumluluklarından dolayı Meclis soruşturması yolu ile Yüce Divan'a sevk edilebilmesi kararı yürürlüğe girmiştir. Bakanlıkların kurulması, kaldırılması, görev, sorumlulukları, yetkileri ve teşkilat yapılarının Cumhurbaşkanlığı kararnamesi ile düzenlenmesi dolayısıyla yürütme alanı dahilinde olan tüm kişi, kurum ve kuruluşların Cumhurbaşkanlığına bağlanması kararı verilmiştir

- $\quad$ Anayasanın 116. Maddesinde yapılan değişiklik ile Cumhurbaşkanlığı ve meclisin karşılıklı fesih hakkı olmasına karar verildi. Cumhurbaşkanı fesih kararını tek başına alırken meclis üye tam sayısının beşte üç çoğunluğu ile karar alabileceği kabul edildi. Dolayısıyla fesih durumu söz konusu olduğunda yürütme ve yasama düşerek eş zamanlı seçimlere gidecektir. İstisnai durum olarak ise Cumhurbaşkanının ikinci döneminde meclis bu yetkisini kullanır ise Cumhurbaşkanı bir defa daha aday olabilecektir.

- $\quad$ Anayasanın 119. Maddesinde yapılan değişiklik kapsamında sıkıyönetim kaldırılmış, olağanüstü hal ilan edilmesinde ise MGK'dan görüş alınması zorunluluğu sona erdirilmiştir. Yürütme yetkisinden dolay1 Cumhurbaşkanına OHAL ilan etme ve OHAL sürecinde KHK çıkarma yetkisi verildi. Cumhurbaşkanının OHAL yetkisini kullanması durumunda kararnamelerin üç ay içerisinde TBMM tarafından karar bağlanarak nihai hal alması zorunluluğu getirildi. TBMM'nin KHK'ları karara bağlayamaması durumunda OHAL'de çıkarılan Cumhurbaşkanlığı kararnamelerinin yürürlükten kalkmasına karar verildi.

- Anayasanın 142. Maddesinde yapılan değişiklik ile Askeri mahkemeler kaldırılarak yargının sivilleştirilmesi sağlandı.

- $\quad$ Anayasanın 159. Maddesinde yapılan değişiklik ile birlikte HSYK yapısı yeniden tasarlanarak adındaki yüksek ibaresi kaldırıldı. HSK'nın başkanı olarak Adalet Bakanı belirlendi. Adalet Bakanlığı Müsteşarı da kurulun doğal üyesi olarak önceki sistemde belirtilen durum geçerli kabul edildi. Kurulun üye tam sayıs1 22'den 13'e düşürüldü. Üye seçimlerinde ise 11 üyeden dördünün Cumhurbaşkanı 7'sinin ise meclis tarafından belirlenmesine karar verildi.

- $\quad$ Anayasanın 161-164. Maddeleri arasında yer alan hükümlerin sadeleştirilmesi ile yeni sisteme uyumlu hale getirilmesi sağlandı. Bütçe ile ilgili olan bu maddeler Cumhurbaşkanı tarafından bütçe tasarılarının hazırlanıp Meclise sunulması kuralı ile düzenlendi. Bütçe kanununun meclis tarafindan kabul edilmemesi veya kararın gecikmesi durumunda geçici bütçe kanunu çıkarılarak kanun kabul edilene kadar bir önceki yılın bütçesinin güncel ekonomik değerler gözetilerek uygulanması kuralı yürürlüğe girdi. Dolayısıyla bütçe görüşmelerinin uzun sürmesinden kaynaklı kurum ve kuruluşların hizmet verememesi sorununun önüne geçilmiş oldu.

- Cumhurbaşkanlığı Hükümet Sistemi dolayısıyla yapılan değişikliklerle anayasanın ilgili maddelerinde kelime ve ibarelerde değişiklik hakkı tanındı. Değişiklikler yapılırken bazı maddelerin yürürlükten kalkması da bu madde ile belirlenmiş oldu.

- İlk Cumhurbaşkanlığ1 ve milletvekili seçiminin 3 Kasım 2019 tarihinde yapılması, sistem değişikliğinden dolayı meclis içtüzüğü değişikliğinin ve diğer düzenlemelerin altı ay içerisinde yapılmasına karar verildi. HSK üye seçimlerinin ise kanunun yürürlüğe girmesini takip eden bir ay içerisinde yapılmasına karar verildi. Askeri yargının ise dört ay içerisinde kaldırılması yürürlüğe girmiş oldu.

Yapılan bu değişiklikler ile yeni sistem yürürlüğe girmiş oldu. Bu yapılan değişiklikler ile birlikte 2007 referandumu sonrasında Türkiye siyasal sistemi yarı-başkanlık görünümündeyken, 6771 sayılı kanunun yürürlüğe girmesi ile birlikte sistem başkanlık sistemine dönüşmüştür. Yapılan sistem değişikliğinin erkler üzerindeki etkileri ve yapılan değişiklikler ile birlikte işleyişleri alt başlıklarda ele alınmıştır.

\subsection{Yasama}

Cumhurbaşkanlığı Hükümet sisteminin yürürlüğe girmesi ile birlikte yasama ve yürütme organlarının birbirinden keskin biçimde ayrılması sağlanmıştır. Yasama yetkisi sadece yasama organı üyelerine yani milletvekillerine bırakılmıştır. Dolayısıyla yasama yetkisini kullanan yegane kurum TBMM'dir (Akçay, 2016: 
54). 6771 sayılı kanun kapsamında yasama organı içerisinden çıkan ve kuvvetler ayrılığının mümkün olmadığı bir sistem yerine, doğrudan seçimler ile yasama ve yürütme organının halk oyu ile belirlendiği bir sistem benimsenmiştir. Dolayısıyla kuvvetler ayrıllğı ilkesinin işleyişi kuvvetlendirilmiş, yasama ve yürütme organlarının birbiri içerisinden çıkması durumuna son verilmiştir (Orkun vd, 2016: 125). Yeni hükümet sistemi ile birlikte yasama ve yürütme ilişkilerinin yeniden tanımlandığı bir sürece girilmiştir.

Yeni sistemin yürürlüğe girmesi ile birlikte yasama organı olan TBMM kanun teklifleri ile politika yapım sürecine dahil olmaya başlamıştır. Kanun teklifleri ise genel kurula gelmeden önce ilgili komisyonlarda görüşülerek biçimlendirilmektedir. Komisyon toplantılarına komisyon başkanına ek olarak Cumhurbaşkanı yardımcısı ya da bakan katılabilir. Yürütmenin kanun yapım sürecine sadece komisyonlarda ve nispeten dahil olduğunu söylemek mümkündür. Komisyonlarda sona gelen çalışmalar genel kurulda görüşülerek nihai karara var1lır (Akman, 2019: 43). Bu komisyonlar ise (TBMM Komisyonlar);

- $\quad$ Adalet Komisyonu

- $\quad$ Anayasa Komisyonu

- $\quad$ Avrupa Birliği Uyum Komisyonu

- $\quad$ Bayındırlık İmar, Ulaştırma ve Turizm Komisyonu

- $\quad$ Çevre Komisyonu

- $\quad$ Dişişleri Komisyonu

- Dilekçe Komisyonu

- Güvenlik ve İstihbarat Komisyonu

- $\quad$ İçişleri Komisyonu

- İnsan Haklarını İnceleme Komisyonu

- $\quad$ Kadın Erken Fırsat Eşitliği Komisyonu

- $\quad$ Kamu İktisadi Teşebbüsleri Komisyonu

- Milli Eğitim, Kültür, Gençlik ve Spor Komisyonu

- $\quad$ Milli Savunma Komisyonu

- $\quad$ Plan ve Bütçe Komisyonu

- $\quad$ Sağlık, Aile, Çalışma ve Sosyal İşler Komisyonu

- $\quad$ Sanayi, Ticaret, Enerji, Tabii Kaynaklar, Bilgi ve Teknoloji Komisyonu

- $\quad$ Tarım, Orman ve Köyle İşleri Komisyonu

Anayasa ile belirtilen yetkiler dışında hiçbir kurum, kuruluş ve kişi devletin yetkilerini kullanamaz. Egemenliğin millete ait olduğu bir yönetim biçiminde bu yetki millet tarafindan kişilere belirli dönemlerle sınırlı olmak üzere seçimler aracılığı ile bırakılır. Buna vatandaşa vekalet eden vekillik eden anlamında milletvekili denilir. Seçilen parlamento üyeleri, halk adına yasa yapma yetkisine sahip olurlar. Bu yetkiyi anayasanın 87. Maddesi ve diğer maddeleri gereğince TBMM kullanır. Yani yasama yetkisi TBMM'dedir. TBMM'nin görev ve yetkilerini ise şu biçimde saymak mümkündür (tbmm.gov.tr).;

- Kanun yürürlüğe sokmak, yürürlükte olan kanun üzerinde değişiklik yapmak veya yürürlükte olan kanunu kaldırmak

- Yürütme üzerinde denetimi Cumhurbaşkanı yardımcıları ve bakanları denetleyerek sağlamak

- Bütçe tekliflerini görüşmek ve kabul etmek

- Para basımı ile ilgili kararları vermek

- Savaş durumuna karar vermek

- Uluslararası anlaşmaları onaylamak

- Aflarla ilgili karar vermek 
- Anayasayı değiştirmek

- Kalkınma ile ilgili plan proje ve programları onaylamak

- TBMM içtüzüğünü hazırlamak

- OHAL esnasında Cumhurbaşkanlığı kararnamelerini onaylamak, değişiklik yapmak veya reddetmek

- OHAL kararlarını onaylamanın yanı sıra dört ayı geçmeyecek şekilde uzatmak veya kaldırmak

- Meclis Başkanını, başkanlık divanı üyelerini belirlemek

- HSK üyelerinin bir kısmını seçmek

- Kamu Başdenetçisini ve Kamu Denetçilerini seçmek

- TBMM seçimlerinin yenilenmesine karar vermek

- Yürütme üyelerin Yüce Divana yargilanmak üzere sevk etmek

- Parlamento üyelerinin dokunulmazlıklarını kaldırmak

- Vekilliklerin düşürülerek meclis üyeliklerinin sonu erdirilmesi kararını vermek

- TSK'nın yurt dışına operasyon düzenlemesi, sürekli kuvvet bulundurması, asker sevk etmesi gibi konulara izin vermek

- Yabancı devletlerin silahlı kuvvetlerinin Türkiye'de bulunmasına izin vermek

- KİT'leri denetlemek

Yasa ile belirlenen yetkilerini bu şekilde sıralamak mümkündür. Yeni yönetim modeline geçilmesi ile birlikte nüfus artışı da hesaba katılarak 550 olan milletvekili sayısı 600'e çıkarılarak meclisin daha işlevsel bir hal alması sağlanmıştır. Milletvekili seçilebilmekle ilgili düzenlemelerde ise seçilme yaşını 25'ten 18'e indirerek gençlerin mecliste daha fazla söz sahibi olması ve yasama faaliyetlerine katılması sağlanmıştır. (Anayasa 76. Madde). Yapılan diğer bir değişiklik kapsamında yasama seçimlerinin yürütme ile eşzamanlı olarak 5 yılda bir aynı gün yapılmasına karar verilmiştir (Anayasa 77. Madde). Yeni sistem ile birlikte yürürlükte olan bazı uygulamalar kaldırılmıştır. Meclisin bilgi edinme ve denetim araçlarından olan gensoru ve güvenoyu kaldırılmıştır. Bunun en önemli nedeni ise yürütme organının meclise karşı siyasi sorumluluk sağlamasına neden olan bu uygulamaların kuvvetler ayrıllı̆g ilkesine tezatlık oluşturduğundan kaldırılması bir zorunluluk haline gelmiştir. Ancak meclisin yürütme üyelerini denetimi sürdürülmüş, belirli bir oy çoğunluğu ile yüce divana sevk edebilmesi benimsenmiştir (Turan, 2018: 51). Toplamda 18 komisyon ile yasama faaliyetlerinde bulunan TBMM yasa yapma, düzenleme veya yürürlükten kaldırma ile ilgili yetkili tek organdır.

Anayasanın 116. Maddesinde yapılan değişiklik dolayısıyla yasama ve yürütme organlarına karşılıklı fesih hakkı verildi. Bu fesih durumu sistem tıkanıklıklarının önüne geçmek olarak nitelendirildi. Cumhurbaşkanı bu kararı tek başına alabilirken meclis ise beşte üç çoğunlukla bu kararı alabilmektedir. Fesih durumunda iki erkin de görev süresi sona ererek seçimlere giderler. Anayasanın 119. Maddesinde yapılan değişiklik gereği Cumhurbaşkanına OHAL ilan etme ve bu süreçte KHK çıarma yetkisi verilmiştir. Ancak bu yetki yasama denetiminde kullanılmaktadır. Cumhurbaşkanının bu yetkisini kullanması durumunda söz konusu kararnameler üç ay içerisinde TBMM tarafından karara bağlanmak zorundadır. Karara bağlanmayan kararnameler yürürlükten kalkmaktadır (Anayasa 116-119. Madde).

Anayasanın 83. Maddesi ile yasama faaliyetlerinden dolayı bir vekilin dokunulmazlığı bulunmaktadır. $\mathrm{Bu}$ dokunulmazlık; meclis çalışmaları esnasında sözlerinden, kullandığı oydan, sunduğu düşüncelerinden, meclis divanının teklifi üzerine mecliste herhangi başka bir karar alınmadığı sürece bu eylemlerini meclis dışında tekrarlamaktan dolayı sorumlu tutulamazlar. Dolayısıyla Milletvekillerinin Meclis mensubu olmanın verdiği dokunulmazlık zırhına büründüğünden bahsetmek mümkündür. Seçim öncesi veya sonrası bir suç dolayısıyla meclis kararı olmaksızın milletvekili tutuklanamaz, sorgulanamaz, yargılanamaz. Ağır cezanın gerekli olduğu durumlarda seçimden önce soruşturma başlamış ise anayasanın 14. Maddesindeki durumlar bu hükmün dışında tutulur. Ancak soruşturmayı yürüten makam bu durumu doğrudan TBMM'ye bildirmekle yükümlüdür. Meclis üyesinin hakkında açılan seçim öncesi bir soruşturmanın gene seçim öncesinde verilmiş bir hükmü varsa üyelik sıfatının sona ermesi beklenir, süre aşımı bu durumda işletilmez. Yeniden seçilen bir vekilin soruşturma ve kovuşturması meclisin dokunulmazlı̆̆ 1 kaldırmasına bağlıdır. Dolayısıyla TBMM mensubu olmanın verdiği dokunulmazlık gene meclis tarafindan kaldırabilir (Anayasa 83. Madde). Dokunulmazlığın 
kaldırılması ise TBMM içtüzüğü ile belirlenir. Dokunulmazlığın kaldırılması söz konusu olduğunda Meclis başkanı tarafından Adalet ve anayasa komisyonları üyelerinden oluşan karma komisyona konu havale edilir. Karma komisyon başkanı dokunulmazlık dosyalarının incelenmesinin ardından milletvekilliği dokunulmazlığının kaldırılmasına karar verebilir (Özbudun, 2005: 112).

2839 sayılı kanunun 10,11 ve 12 maddelerine göre 18 yaşını dolduran her Türk vatandaşı milletvekili seçilebilir. Diğer kıstaslar ise; İlkokul mezunu olmak, kısıtlı olmamak, askerlikle ilişiği olmamak, kamu hizmetinde yasaklı olmamak, taksirli suçlar haricinde bir yıl veya daha fazla hapis cezası almamış olmak, süresine bakılmaksızın ağır hapis cezasına mahkum olmamış olmak, basit veya nitelikli zimmet, rüşvet, irtikap, yüz kızartıcı suçlar, inancı kötüye kullanma, dolanlı iflas, ihaleye fesat karıştırma, devlet sırlarını açıklama vb. gibi suçlarla mahkum olmamış olmak, TCK ikinci kitabının ilk babında yazılı suçlardan veya bu suçların işlenmesini açık biçimde tahrik etme suçundan mahkum olmamak, TCK'nın 536. Maddesinin 1, 2, 3. F1kralarından yazılı eylemlerle ve 537. Maddenin 1, 2, 3, 4, ve 5. Fikralarından belirtilen eylemlerden dolay1 siyasi veya ideolojik suçlardan cezalandırılmış olmamak, terör eylemlerinden dolayı mahkumiyet almış olmamak olarak sayılabilir (2839 Sayılı Kanun).

\subsection{Yürütme}

6771 sayılı kanun kapsamında anayasada yapılan değişiklik ile Cumhurbaşkanı devletin başıdır ifadesine ek olarak devletin de başıdır ifadesi getirilmiştir (Anayasa 104. Madde). Dolayısıyla bu değişiklik ile birlikte yürütme alanına özel bir durum olmakla birlikte düzenlemeler yapma yetkisi de Cumhurbaşkanına verilmiştir. Anayasanın 106. Maddesinde yapılan değişiklik ile yürütme organında görevli olan birinin yasama üyesi olamayacağı, atandığı dönemde yasama üyeliği var ise yasama üyeliğinin sona ereceği şartı getirilerek yasama ve yürütme arasındaki çizgi keskinleşmiştir. Dolayısıyla önceki sistemde olduğu gibi yürütme yasamadan çıkmayacaktır. Yasama ve yürütme organları birbirlerinden bağımsız olacaktır.

Yürütmenin başı olarak nitelendirilen Cumhurbaşkanının anayasanın 101 ve 102. maddelerinde yapılan değişiklikler sonucunda seçilebilme, adaylık ve görev süresi şartları;

- Kırk yaşını doldurmuş olmak

- Yükseköğrenim mezunu olmak

- Milletvekili seçilebilme yeterliliğine sahip Türkiye Cumhuriyeti vatandaşı olmak

- Bir kimse bir dönemi 5 yıl olmak üzere, en fazla iki dönem Cumhurbaşkanlığ yapabilir.

- Son seçimde en az \%5 ve üzeri oy almış siyasi partiler Cumhurbaşkanı adayı gösterebilir

- Yüzbin seçmenin imzası ile Cumhurbaşkanı adayı gösterilebilir.

Cumhurbaşkanı adayı yasama üyesi olabilir. Seçilmesi durumunda TBMM üyeliği sona erer. Genel oy ile yapılan Cumhurbaşkanlığı seçimlerinde geçerli oyların salt çoğunluğunu elde eden aday Cumhurbaşkanı olarak görevi devralır. Eğer ilk turda salt çoğunluk sağlanamaz ise seçimi takip eden ikinci Pazar günü en çok oyu almış ilk iki aday arasında seçim tekrarlanır ve geçerli oyların çoğunluğunu alan aday Cumhurbaşkanı seçilir. Seçimlerin tamamlanmasına kadar geçen sürede yeni Cumhurbaşkanı seçilene kadar mevcut Cumhurbaşkanı görev yapar. Cumhurbaşkanlığı seçimleri ile ilgili usul ve esaslar kanunlarla düzenlenir (Tunç, 2019:123). Seçilen Cumhurbaşkanı anayasanın 103. Maddesinde yer alan metinle TBMM'de yemin ederek göreve başlar.

Yürütmenin başı olan Cumhurbaşkanının görev ve yetkilerini anayasanın 104. Maddesine göre;

- Devletin ve yürütmenin başıdır. Yürütme yetkisi Cumhurbaşkanına aittir.

- Devlet başkanı sıfatı ile Cumhurbaşkanı Türkiye Cumhuriyetin'in ve vatandaşlarının birliğini temsil eder.

- Anayasanın uygulanmasının yanı sıra, devlet kurum ve kuruluşlarının düzgün çalışmalarını tesis eder.

- Gerekli gördüğü durumlarda yasama yılının açılış gününde TBMM'de konuşma gerçekleştirir.

- Ülkenin iç ve dış politikalarıyla ilgili meclise mesaj verebilir.

- Kanunları tekrar görüşülmek üzere TBMM'ye gönderebilir, kabul edilen kanunları yayımlar 
- TBMM içtüzüğünde belirli hükümlerin anayasaya aykırı oldukları gerekçesi ile anayasa mahkemesine iptal davası açabilir

- Cumhurbaşkanı yardımcılarını atar ve sayılarını belirler veya görevlerine son verebilir.

- Bakanları atar veya görevden alır.

- Üst kademe bürokratları atar, görevlerine son verir.

- Atamalarla ilgili usul ve esasları Cumhurbaşkanlığı kararnamesi aracılığı ile düzenler

- Yabancı devletlere Türkiye Cumhuriyeti temsilcilerini gönderir, Türkiye Cumhuriyeti'ne gönderilen yabanci temsilcileri kabul eder.

- Uluslararası anlaşmaları onaylamak ve yayınlamak

- Anayasa değişikliğine ilişkin kanun tekliflerini gerekli görmesi durumunda referanduma sunmak

- Milli güvenlik politikalarını belirleyerek gerekli gördüğü tedbirleri alabilir

- Başkomutanlık sıfatını TBMM adına kullanır.

- Gerekli gördüğü durumlarda TSK’nın kullanılmasına karar verir.

- Genel veya özel af çıkarabilir.

- Yürütme alanı ile ilgili olmak üzere Cumhurbaşkanlığı kararnamesi çıkarmak

- Kanunların uygulanmasını sağlamak üzere kararname çıkarabilir. Cumhurbaşkanı, yürütme yetkisine ilişkin konularda Cumhurbaşkanlığı kararnamesi çıkarabilir. Anayasanın ikinci kısmının birinci ve ikinci bölümlerinde yer alan temel haklar, kişi hakları ve ödevleriyle dördüncü bölümde yer alan siyasi haklar ve ödevler Cumhurbaşkanlığı kararnamesiyle düzenlenemez. Anayasada münhasıran kanunla düzenlenmesi öngörülen konularda Cumhurbaşkanlığı kararnamesi çıkarılamaz. Kanunda açıça düzenlenen konularda Cumhurbaşkanlığı kararnamesi çıkarılamaz. Cumhurbaşkanlığı kararnamesi ile kanunlarda farklı hükümler bulunması halinde, kanun hükümleri uygulanır. Türkiye Büyük Millet Meclisinin aynı konuda kanun çıkarması durumunda, Cumhurbaşkanlığı kararnamesi hükümsüz hale gelir.

Anayasadan aldığı bu yetkileri yürütmenin başı olarak Cumhurbaşkanı kullanır. 10.07.2018 tarihinde resmi gazetede yayımlanan 1 numaralı Cumhurbaşkanlığı kararnamesine göre Cumhurbaşkanlığ 1 Teşkilatı (https://www.mevzuat.gov.tr/MevzuatMetin/19.5.1.pdf) şekil 1'de gösterilmiştir.

Şekil 1: Cumhurbaşkanlığı Teşkilatının Yapısı 
Türk Yönetim ve Ekonomi Araştırmaları Dergisi, 2021, C.2, S.1, ss.56-76.

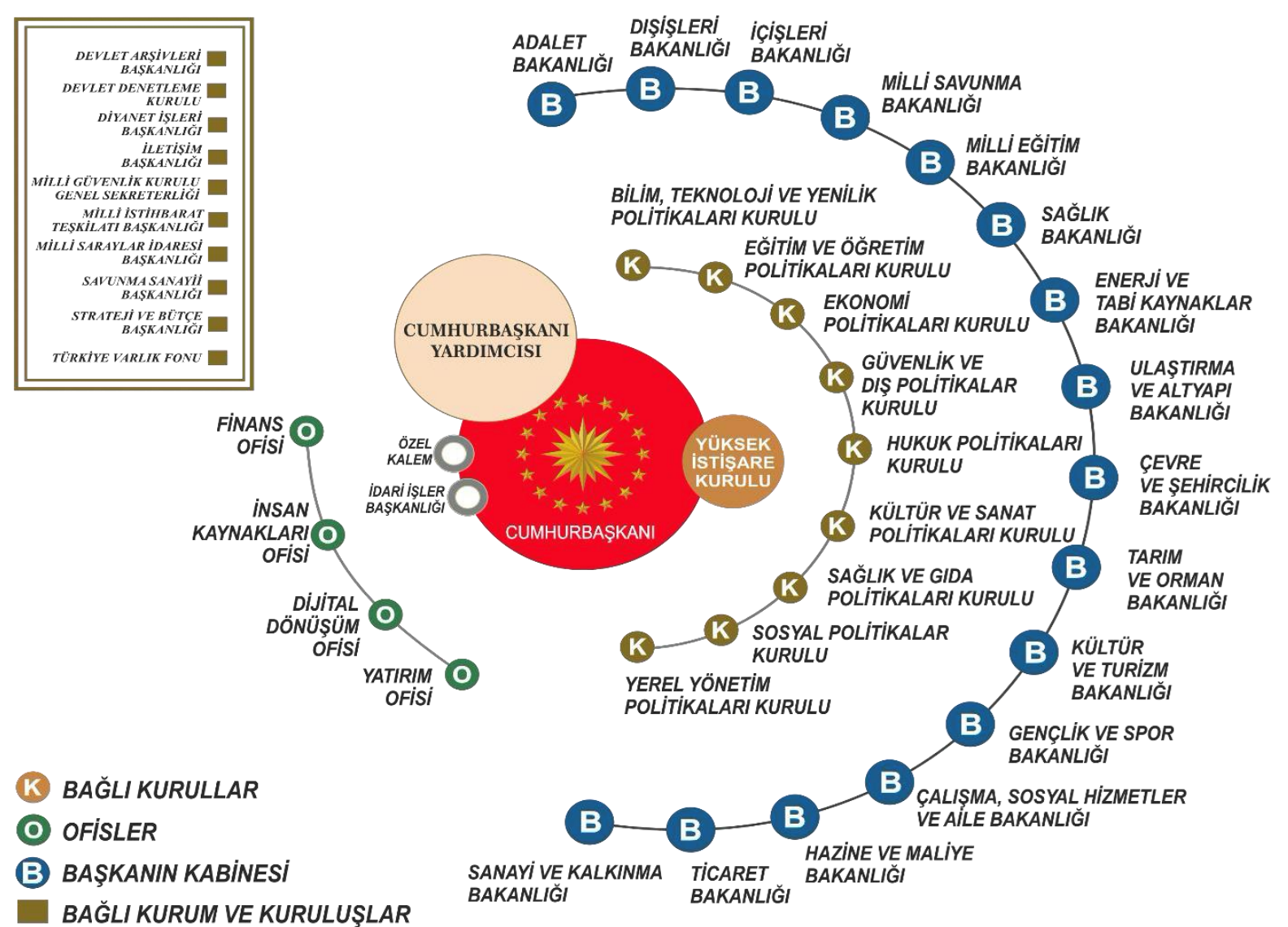

\section{Kaynak: Öztürk ve Tozak, https://d1wqtxts1xzle7.cloudfront.net/)}

Yürütme organı şekil 1'de gösterildiği üzere incelenecek olursa; Yürütme yetkisi sadece Cumhurbaşkanında olmasına karşın Cumhurbaşkanı bunu teşkilatı ile birlikte yürütür. Doğrudan halkoyu ile seçilen Cumhurbaşkanı kamu politikalarının uygulayıcısı olması, toplum ihtiyaç ve taleplerinin karşılanması gibi yürütme ile ilgili konularda baş aktör konumundadır. Dolayısıyla bu politikaların oluşturulması, uygulanması konusunda bakanlıklar arasında koordinasyonu sağlayacak idari yapılanmayı kontrol edecek üst düzey görevlileri Cumhurbaşkanı atayacak veya görevden alacaktır. Bu görev ve sorumlulukların etkili ve rasyonel bir biçimde kullanılarak sonuç alınabilmesi için Cumhurbaşkanına bağlı birçok birim ve kişilerden oluşan bir teşkilat oluşturulması zorunluluğu ortaya çıkmıştır. Bu nedenle Cumhurbaşkanlığında oluşturulan of is ve kurullar büyük önem taşımaktadır (Sobacı vd, 2018: 2).

Koordinasyon toplantıları ile müşterek alanlardaki görev ve politikalara ilişkin koordineyi sağlamak amacıyla ilgili bakanlar, kurum ve kuruluşların üst düzey yöneticileri ve ilgili politika kurulu başkanvekilinin katılımı ile koordinasyon toplantısı yapılabilir. Bu toplantı neticesinde tespit edilmiş olan hususlar Cumhurbaşkanına sunulur. Bu koordinasyon toplantılarına Cumhurbaşkanı veya görevlendireceği politika kurulu başkanvekili yada ilgili bakan başkanlık eder. Bu toplantılara ilişkin bütün süreç politika kurulları tarafından gerçekleştirilir (1 nolu Cumhurbaşkanlığı kararnamesi 3. Bölüm). Cumhurbaşkanlığı hükümet sisteminde Cumhurbaşkanlığı politikalar kurulları politikaları oluşturucu bakanlıklar ile bu politikaların uygulayıcısı konumundadır.

Cumhurbaşkanı yardımcısı anayasanın 106 maddesi gereğince Cumhurbaşkanı tarafindan bir veya birden fazla olmak üzere atanır. Cumhurbaşkanlığı makamının herhangi bir nedenle boşalması durumunda 45 gün içerisinde seçime gidilmesi gereklidir. Bu süreçte Cumhurbaşkanı yardımcılarından en yaşlı olanı Cumhurbaşkanlığ 1 seçilene kadar vekaleten yürütür ve Cumhurbaşkanı yetkilerini kullanır. Cumhurbaşkanının yurt dışına çıkma, hastalık gibi geçici sebeplerle görevden ayrılması durumunda ise Cumhurbaşkanı yardımcısı Cumhurbaşkanına vekalet eder ve ona ait yetkileri kullanır. Cumhurbaşkanı yardımcıları ve bakanlar milletvekili seçilebilme yeterliliğine sahip olanlar içerisinden Cumhurbaşkanı tarafından atanır ve görevden alınır. Atanan yürütme görevlisi olan Cumhurbaşkanı yardımcısı ve bakanlar TBMM önünde and içerek göreve başlarlar, yasama ile ilişiği olanların yasama üyelikleri atanmaları durumunda sona erer. Yürütme kurulu üyesi olan Cumhurbaşkanı Yardımcısı ve bakanlar sadece Cumhurbaşkanına karşı sorumludur. Anayasanın 101 ve 102. maddelerinde yapılan değişiklik sonucunda Cumhurbaşkanı seçilen kişinin varsa siyasi parti ilişiği kesilir ibaresi kaldırılarak Cumhurbaşkanının partili olmasının önü açılmıştır. 
Politika kurullarının her birisi en az 3 üyeden oluşur. Kurul üyeleri Cumhurbaşkanı tarafından atanır ve Cumhurbaşkanına karşı sorumludur. Atanan 3 üyeden birisi başkanvekili olarak görevlendirilir. Bu kurulların görev ve yetkileri şunlardır (1 nolu Cumhurbaşkanlığı Kararnamesi, Dördüncü Kısım, 22. Madde). ;

- Cumhurbaşkanının alacağı kararlar ve oluşturulacak politikalarla ilgili öneriler vermek

- Geliştirilen politika ve strateji tavsiyelerinin Cumhurbaşkanı tarafindan uygun görülenleri üzerinde gerekli çalışmaları yapmak

- Küresel değişim neticesinde oluşan ani değişimlere karşı politika önerileri ve stratejiler geliştirmek

- Görev alanları dahilinde bakanlıklar, kurum ve kuruluşlar, sivil toplum, uzman kişiler, sektör temsilcilerinin görüssleri ile uygulanan politikaları izlemek ve bunlarla ilgili raporu Cumhurbaşkanına sunmak

- Sivil toplum, uzman kişiler, sektör temsilcileri, ilgili kurum ve kuruluşlar, bakanlıkların davet edilmesi ile genişletilmiş kurul toplantıları düzenlemek

- Görev alanına giren konularla ilgili talep ve ihtiyaçlar doğrultusunda etki analizi yapmak veya yaptırmak

- Cumhurbaşkanı tarafindan verilen diğer görevleri yerine getirmek

Cumhurbaşkanlığı hükümet sisteminde Cumhurbaşkanı anayasada belirtilen görev yetkilerini icra ederken halktan gelen talep ve istekleri karşılamak ve bunlara yönelik kamu politikalarını ortaya çıkaracak olan Cumhurbaşkanlığı politika kurulları 1 nolu Cumhurbaşkanlığı kararnamesi ile yasal zeminde kendisine yer bulmuştur (Akınc1, 2019: 79).

Cumhurbaşkanlığı hükümet sisteminde en büyük farkl1lıklardan bir diğeri ise eski uygulamaya göre Başbakan ve bakanlar kurulunun yürütme alanında sahip olduğu yetkilerin tamamının Cumhurbaşkanına devredilmesidir. Dolayısıyla Bakanlar Kurulu tarafindan meclisten alınan KHK çıkarma yetkisi de bu kapsamda Cumhurbaşkanına geçmiştir. Bu yetki üç sınır ile Cumhurbaşkanı tarafından kullanılmaktadır. Bunlar (Çolak, 2017: 55);

- Kişi hak ve özgürlükleri, siyasi hak ve hürriyetler ile ilgili kararname düzenlenemez

- Kararname çıkarılabilmesi için o konu ile ilgili kanunlarda düzenleyici, uygulanabilir ve açık hükümlerin bulunmaması gereklidir.

- Kararnameler ile kanunlar aynı konuda farklı hükümler içeriyorsa kanun hükümleri uygulanır, kararname yürürlükten kalkar

6771 sayılı kanun kapsamında yapılan bir diğer değişiklik ise Cumhurbaşkanının cezai sorumluluk kazanmasıdır. Anayasanın 105. Maddesinde yapılan değişiklik ile Cumhurbaşkanının görevi ile ilişkili veya diğer konularla ilgili bir suç işlediği iddiası ile TBMM üye tam sayısının salt çoğunluğu ile verilecek bir önerge ile soruşturma açılması istenilebilir. Meclis söz konusu önergeyi bir ay içerisinde görüşerek üye tam sayısının beşte üç çoğunluğunun gizli oyuyla soruşturma açılmasına karar verebilir. Soruşturma açılması durumunda meclisteki siyasi partilerin üye sayıları nispetinde on beş kişilik bir komisyon tarafından soruşturma yürütülerek bir rapor hazırlanır. Soruşturma raporu Meclis başkanlığı tarafından on gün içerisinde dağıtılarak genel kurulda görüşülür. TBMM üye tam sayısının beşte üç çoğunluğunun gizli oy onayı ile Yüce Divan'a sevk kararı alabilir. Yüce divan yargılamasını üç ay içinde tamamlamalıdır, aksi durumda bir seferlik üç aylık ek süre verilebilir (tccb.gov.tr).

\subsection{Yarg1}

Türkiye Cumhuriyeti'nde Anayasal yargı organı Anayasa Mahkemesi'dir. Anayasa Mahkemesi kuruluşu ve yargılama usulleri 2949 sayılı kanunla belirtilmiştir. Baktığ yargı konuları sınırlıdır. Anayasa Mahkemesinin temel görevi kanunların anayasaya aykırılığı incelemektir. Aynı şekilde KHK'ların, TBMM iç tüzüğünün Anayasaya şekil ve esas bakımından aykırıllı̆ı gerekçesiyle Cumhurbaşkanı veya meclis üye tam sayısının beşte biri üyenin başvurusu ile açılan iptal davalarına bakar. Ayrıca yüksek devlet görevlilerini görevleri ile işledikleri suçlardan dolayı Yüce Divan sıfatı ile yargılar (Süren, 2009: 406).

Anayasa Mahkemesi olağanüstü ve savaş durumlarında çıkarılan Cumhurbaşkanlığı kararnamelerinin şekil ve esas bakımından Anayasaya aykırılığı iddiasıyla dava açamaz. Usule göre yürürlüğe girmiş uluslararası anlaşmalar hakkında anayasa mahkemesine iptal davası açılamaz. Norm denetimi yapan Anayasa mahkemesine 
iki tür başvuru usulü vardır. Bunlar; iptal davaları ve itiraz yoludur. Başvuru usulünün uygun olmasının ardından yapılan yargılamada anayasa mahkemesi iptal veya red kararı verebilir (anayasa.gov.tr).

"Anayasa mahkemesi on beş üyeden oluşur. Anayasa Mahkemesi üye tam sayısı olan 15'in 12'si Cumhurbaşkanı tarafindan 3'ü ise TBMM tarafindan atanarak göreve başlar. TBMM iki üyeyi sayıştay başkan ve üyeleri arasından, her boş yer için üçer aday içinden bir üyeyi ise baro başkanlarının serbest avukatlar arasından gösterecekleri üç aday içinden yapacağı gizli oylamayla seçer. TBMM'de yapılacak seçimde, her boş üyelik için ilk oylamada üye tam sayısının üçte iki, ikinci oylamada üye tam sayısının salt çoğunluğu aranır. İkinci oylamada salt çoğunluk sağlanamaz ise bu oylamada en çok oy alan iki aday için üçüncü oylama yapılır, üçüncü oylamada en fazla oy alan üye seçilmiş olur ',(6771 sayılı kanun, 16. Madde). Cumhurbaşkanı ise üç üyeyi Yargıtay, iki üyeyi Danıştay üyeleri arasından her boş yer için gösterilen üçer aday içinden; en az ikisi hukukçu olmak üzere üç üyeyi YÖK'ün kendi üyesi olmayan yükseköğretim kurullarının hukuk, iktisat ve siyasal bilimler dallarında görev yapan öğretim üyeleri arasından göstereceği üçer aday içinden, dört üyeyi üst düzey yöneticileri, serbest avukat, birinci sınıf hakim savcı ile en az beş yıl raportörlük yapmış Anayasa Mahkemesi raportörleri arasından seçer (6771 sayılı kanun, 16. Madde). Anayasa mahkemesi üyeleri arasından gizli oy ile üye tam sayısının salt çoğunluğu esasıyla dört yıl için bir başkan iki başkanvekili seçilir. Süresi biten başkan ve başkanvekilleri yeniden seçilmesi için engel bulunmamaktadır. Ancak bir kişi iki defa anayasa mahkemesi üyesi olarak görev yapamaz. On iki yıl için seçilen anayasa mahkemesi üyeleri altmış beş yaşını doldurduklarından emekliye ayrılırlar. Kırk beş yaşını doldurmayan kişiler Anayasa Mahkemesi üyeliğine seçilemez (anayasa.gov.tr).

6771 sayılı kanun değişikliği kapsamında yargı organında da bir dizi değişiklikler gerçekleşmiştir. Anayasanın 9. Maddesine yargının bağımsızlığına ek olarak tarafsızlığı ibaresi eklenmiştir. Dolayısıyla anayasanın 9. Maddesi "yargı yetkisi, Türk Milleti adına bağımsız ve tarafsız mahkemelerce kullanılır biçiminde düzenlenmiştir. Anayasal bir boşluk olarak nitelendirilen tarafsızlık kavramına bu sayede anayasada yer verilmiş oldu (Uzun, 2018: 413). 6771 sayılı kanun değişikliği kapsamında Askeri Mahkemeler kaldırılarak yargının sivilleşmesi sağlanmıştır (Turan, 2018: 52). Yine aynı kanun değişikliği ile birlikte HSK'nın yapısı değişmiştir. Daha öncesinde HSYK olan kurumun adından yüksek ibaresi çıkarılarak HSK halini almıştır. Daha öncesinde üyelerin bir kısmının hakim ve savcılar tarafından belirlendiği seçim usulüne son verilerek bütün üyelerin TBMM ve Cumhurbaşkanı tarafindan seçilmesine karar verilmiştir. HSK'nın daire sayısı 3'ten 2'ye, üye tam sayısı ise 22'den 13'e indirilmiştir. Seçilen üyeler dört yıl için görev yapar (Uzun, 2018: 417).

Tablo 4. HSK Üyelerinin Geldiği Kaynaklar

\section{Üyelerin Geldiği Kaynaklar}

Adalet Bakanı

Adalet Bakan Yardımcısı

TBMM Genel Kurulu

Cumhurbaşkanı

\section{Sayı}

1

1

7

4

Kaynak: https://www.hsk.gov.tr/Hakkimizda.aspx

\section{SONUÇ}

Yürütmenin yasamanın içerisinden çıkmasına son veren yeni sistemin yürürlüğe girmesi ile birlikte kuvvetler ayrılığı ilkesinin daha belirginleştiği görülmektedir. Anayasanın 106 maddesindeki değişiklik ile bir kişi hem yasamada hem yürütmede görev alamaz. Yürütme üyesi olan kişinin yasama üyeliği varsa sona erer. Dolayısıyla yasama ve yürütme kuvvetleri birbirinden ayrılmıştır. İşleyişin Anayasaya ve kanunlara uygun devam etmesi yasama denetiminde gerçekleşir, yasama organı olan TBMM kanun koymak, değiştirmek veya yürürlükte olan bir kanunu kaldırmak ile ilgili yegane sorumludur. Türk milleti adına Bakanlar Kurulunu ve 
Bakanları denetlemek TBMM'nin görevleri arasındadır. Dolayısıyla yasama denetimi sayesinden yürütme organının denetleme görevi meclise aittir. Ancak bu denetim önceki sistemde olduğu gibi güvenoyu ve gensoru ile yapılmamaktadır. Meclis araştırması ve meclis soruşturması aracılığı ile bu denetimler gerçekleşmektedir. Yürütme üyelerinin veya Yürütmenin başı olan Cumhurbaşkanının yargılanması da yine meclis aracılığı ile gerçekleşmektedir (Tekin, 2016: 150).

Yeni sistemin ortaya çıkmasındaki en büyük gerekçelerden birisi kuvvetler ayrılığı ilkesinin yumuşak uygulanmasından dolayı sistem tıkanıklarının oluşması, erken seçim, koalisyonlar, siyasi istikrarın olmayışı gibi sorunlar ortaya çıkmaktadır. Yeni sistemin yürürlüğe girdiği 24 Haziran 2018 seçimlerinde yasama ve yürütmenin koordineli çalışması için 'Güçlü Meclis Güçlü Hükümet "sloganı kullanılmıştır. Seçim kampanyası döneminde tüm siyasi partiler mecliste çoğunluğu elde edebilmek için çaba göstermiştir (Turan, 2018: 48). 6771 sayılı kanun değişikliği kapsamında parlamenter sisteme ilişkin usul ve uygulamalar kaldırılmış, yasama ve yürütmenin her ikisinin de doğrudan halk oyu ile seçilmesi meşruiyetlerini halktan alması dolayısıyla halka karşı sorumludurlar (Orkun vd, 2016: 125).

6771 sayılı kanun kapsamında anayasanın 101. Maddesinde meydana gelen değişiklik ile bir kişinin en fazla iki dönem Cumhurbaşkanlığı yapması yönetimde yeni yüzlerin, fikirlerin görülebilmesine imkan tanımaktadır. Dolayısıyla makamların kişiselleşmesinin önüne yeni sistem sayesinde geçildiğini söylemek mümkündür. Aynı değişiklik ile anayasanın 104 maddesinde ' 'Cumhurbaşkanı, Devlet başkanı sıfatıyla Türkiye Cumhuriyeti'ni ve Türk Millerinin birliğini temsil eder; Anayasanın uygulanmasını, Devlet organlarının düzenli ve uyumlu çalışmasını temin eder 'biçiminde değişiklik yapılması ile yürütmenin tüm organlar üzerinden denetime sahip olduğunu da söylemek mümkündür. Yani sadece yasama yürütmeyi değil, yürütme organı da yasamayı denetler. Yargı organı ise her iki erki de denetler. 104. Maddenin getirdiği bir diğer değişiklik ile yürütme organında olan çift başlılık ortadan kaldırılarak yürütme yetkisi ve devlet başkanı Cumhurbaşkanıdır biçiminde düzenlenmiştir. Ayrıca bu yasa ile Cumhurbaşkanının veto yetkisi devam ettirilmiştir, ancak meclis gerekli çoğunluk ile vetoyu geçersiz kılarak yasayı yürürlüğe sokabilmektedir.

Anayasanın 105. Maddesinde yapılan değişiklik ile Cumhurbaşkanı cezai sorumluluk kazanmış ve yargılanmasının önü açılmıştır. Bunun kontrolü ve yargılanmasına dair izin ise yasama organı olan TBMM tarafından verilmektedir. Anayasanın 116. Maddesinde meydana gelen değişiklik ile yasama ve yürütme kuvvetlerine karşılıklı fesih hakkı verilmiştir. Fesih hakkını kullanan erk kendi süresini de sona erdirerek birlikte seçimlere gider. İki erkin de seçimleri aynı gün yapılır, seçimler yapılana kadar yasama ve yürütme görevlerine devam eder. 119. madde ile OHAL uygulanması durumunda Cumhurbaşkanı tarafından çıkarılan kararnamelerin meclis onayına tabi tutulması erkler arasında işbirliğinin artmasına imkan tanımışıı. Ayrıca OHAL ilan edilmesi, süresinin azaltılması ve kısaltılması da meclis onayına tabidir.

Anayasanın 161. Maddesinde meydana gelen değişiklik ile "Cumhurbaşkanı bütçe kanun teklifini, malî yıl başından en az yetmiş beş gün önce, Türkiye Büyük Millet Meclisine sunar. Bütçe teklifi Bütçe Komisyonunda görüşülür. Komisyonun elli beş gün içinde kabul edeceği metin Genel Kurulda görüşülür ve malî yılbaşına kadar karara bağlanır. Bütçe kanununun süresinde yürürlüğe konulamaması halinde, geçici bütçe kanunu çıkarılır. Geçici bütçe kanununun da çıkarılamaması durumunda, yeni bütçe kanunu kabul edilinceye kadar bir önceki yılın bütçesi yeniden değerleme oranına göre artırılarak uygulanır "biçiminde düzenlenmesi ile bütçe görüşmelerinden dolayı kamu yatırımlarının yapılamaması, hizmetlerin aksaması durumu ortadan kalkmaktadır. Ayrıca sunulan bütçe önerisine TBMM arttırıcı ve azaltıcı önerilerde bulunamaz, sadece oylama yapabilir. Dolayısıyla sistemde bir tıkanıklık oluşmasının önüne geçilmesi için gerekli düzenlemelerin yapıldığından bahsetmek mümkündür.

Anayasaya yargının bağımsızlığına ek tarafsızlığı ibaresinin eklenmesi ile yeni sistemde yargının bağımsızlığı ve tarafsızlığı anayasal güvence altına alınmış oldu. Sistemde erklerin yani yasama yürütme ve yargının sert bir biçimde ayrı olduğunu, tüm kuvvetlerin tek yerde toplanmadığını ve birbirlerini denetlendiklerini söylemek mümkündür. Sonuç olarak Cumhurbaşkanlığı Hükümet Sisteminin sert kuvvetler ayrılığı ilkesini uyguladığını ancak yasama ve yürütme arasında bir denge ve denetim olduğunu dolayısıyla yasama ve yürütmenin birbirlerini denetledikleri görülmektedir (Akçakaya ve Özdemir, 2018: 932).

\section{KAYNAKÇA}

AĞIR, O., (2017), " Arap Baharı, Güvenlik ve Terör" Türkiye'de Siyaset ve Uluslararası İlişiler Alanında Güncel Tartışmalar Yeni Anayasa, (Ed: Osman Ağır), Seçkin Yayıncılık, Sıłhıye/Ankara ss. 169-208. 
Türk Yönetim ve Ekonomi Araştırmaları Dergisi, 2021, C.2, S.1, ss.56-76.

AKÇAKAYA, M. ve ÖZDEMIR, A., (2018), 'Cumhurbaşkanlı̆ğ Hükümet Sistemi ve Siyasal İstikrar', Üçüncü Sektör Ekonomi Dergisi, 53 (3), ss 922-944.

AKÇAY, E., (2016), 'Cumhurbaşkanlı̆̆ Sisteminde Siyasi Denetim: İdarenin TBMM Tarafindan Denetlenmesi', Ombudsman Akademik, (5), ss. 37-68.

AKINCI, B., (2019), Cumhurbaşkanlığı Hükümet Sistemi: Sisteme Yönelik Tartışmalar ve Çözüm Önerileri, Nobel Bilimsel Eserler, 1. Bask1.

Akınc1, B. (2020). Türkiye'de 24 Haziran 2018 Genel Seçimleri Sonrasinda "Topal Ördek" Tartışması: Cumhurbaşkanlığı Hükümet Sisteminde Olası Riskler ve Karşı Çözümler, Turkish Studies - Economy, 15(1), 9-21.

Anayasa Mahkemesi Görev ve Yetkileri, https://www.anayasa.gov.tr/tr/mahkeme/gorev-ve-yetkileri/normdenetimi/.

ASLAN, S., (2013), Osmanlıdan Cumhuriyete Türkiye'de Siyasal Hayat, Ed:. Ahmet Karadağ, Orion Kitabevi, Altında ğ/Ankara, ss. 35-98.

Cumhurbaşkanlığı Görev ve Yetkileri, https://www.tccb.gov.tr/cumhurbaskanligi/gorev_yetki/, (21.08.2021).

Cumhurbaşkanlığı Teşkilatının Yapısı, Öztürk ve Tozak, https://d1wqtxts1xzle7.cloudfront.net/, (21.08.2021).

ÇİLLILER, Y., (2019), Karşılaştırmalı Siyasal Sistemler Türkiye-ABD, Nobel, Çankaya/Ankara.

ÇİRKİN, F., (2019), 'Temsilde Adalet İlkesi Açısından Seçimlerde İttifak', Hukuk Fakültesi Dergisi, 5 (2), ss. 433-449.

DAĞ, A. E., (2016), Uluslararası İlişkiler ve Diplomasi Sözlüğü, Vadi Yayınları, $\quad$ Bağcılar/İstanbul.

DEMIR, C v.d., (2017), 'Cumhurbaşkanlı̆̆ Hükümet Sisteminin Yönetişimin Temel İlkeleri Bağlamında Incelenmesi', Strategic Public Management Journal, 3 (Özel Say1), ss.138-153.

Faaliyette Olan Siyasi Partiler, https://www.yargitaycb.gov.tr/documents/ek1-1593086424.pdf, (04.04.2020).

GÖKTOLGA, O., (2013), Osmanlıdan Cumhuriyete Türkiye'de Siyasal Hayat, Ed:. Ahmet Karadăg, Orion Kitabevi, Altındağ/Ankara, ss. 1-34.

GÖZLER, K., (2011), Türk Anayasa Hukuku Dersleri, Ekin Kitabevi, Bursa.

GÜLENER, S. ve Miş, N., (2017), Türkiye'de Siyasal Sistemin Dönüşümü ve Cumhurbaşkanlığı Sistemi, Ed:. Nebi Miş ve Burhanettin Duran, SETA, İstanbul, ss.51-81.

GÜZEL, H. C., (2013), 'Türkiye'de Yarı Başkanlık Sistemi Uygulanabilir', Yeni Türkiye Dergisi, (51), ss. 476-479.

http://www.ysk.gov.tr/tr/tarihce/1510, (14.05.2020).

https://www.aa.com.tr/tr/politika/ak-parti-18-yasinda/1555716, (23.05.2020).

KİRIŞ, H. M., (2010), 'TTürk Parti Sisteminde 1980 Sonrası Kutuplaşma ve Dinamikleri’, Yayımlanmamış Doktora Tezi, Süleyman Demirel Üniversitesi Sosyal Bilimler Enstitüsü, Isparta.

KUZU, B., (2017), Her Yönü İle Başkanlık Sistemi Yeni Cumhurbaşkanlığı Modelimiz, Babıali Kültür Yayıncılığı, Ataşehir/İstanbul, 1. Baskı.

KÜÇÜK, A. ve KARADAĞ, A., (2013), Osmanlıdan Cumhuriyete Türkiye'de Siyasal Hayat, $\quad$ Ed.: Ahmet Karadağ, Orion Kitabevi, Altındağ/Ankara ss. 141-222.

KÜÇÜKYILMAZ, M. M., (2011), Türkiye'de Siyasal Katılım Tek Partiden AK Parti'ye Siyasal İslam ve Demokrasi Tartışmaları, Yarın, İstanbul.

$\begin{array}{lllll}\text { Mecliste } & \text { Temsilcisi } & \text { Olan } & \text { Siyasi } & \text { Partiler }\end{array}$ https://www.tbmm.gov.tr/develop/owa/milletvekillerimiz_sd.dagilim).

Mİş, N. ve DURAN, B., (2017), Türkiye'de Siyasal Sistemin Dönüşümü ve Cumhurbaşkanlığı Sistemi, Ed:. Nebi Miş ve Burhanettin Duran, SETA, İstanbul, ss.15-50.

NALBANT, A., (1996), Üniter Devlet, Bölge ve Bölgesel Devlet’, Doktora Tezi, Marmara Üniversitesi Sosyal Bilimler Enstitüsü, İstanbul. 
ORKUN, A. A. vd., (2016), 'Cumhurbaşkanlığı Hükümet Sisteminde Yönetsel Denetim Nasıl Olmalıdır?’, Ombudsman Akademik, (5), ss. 111-136.

ÖZBUDUN, E., (2005), 'Yasama Sorumsuzluğu ve Yasama Dokunulmazlığı: Hukuki Mahiyetleri ve Farklarl”, TBB Dergisi, (59), ss. 109-115.

SAFİ, İ., (2007), Türkiye'de Muhafazakar Siyaset ve Yeni Arayışlar, Lotus, Ankara.

SOBACI, M. Z. vd., (2018), 'Türkiye’nin Yeni Yönetim Modeli ve Cumhurbaşkanlığı Teşkilatı',SETA Pespektif, (206), 6s.

T.C Anayasas1, https://www.mevzuat.gov.tr/MevzuatMetin/1.5.2709.pdf

TBMM Komisyonlar, https://komisyon.tbmm.gov.tr/

TBMM Milletvekilleri Dağılımı, https://www.tbmm.gov.tr/develop/owa/milletvekillerimiz_sd.dagilim

TBMM, Yeni Sisteme Göre Yasama El Kitab1, 2018, https://www.tbmm.gov.tr/yayinlar/Yasama_El\%20Kitabi.pdf.

TEKIN, Y. ve OKUTAN, Ç., (2012), Türk Siyasal Hayatı, Orion Kitabevi, İskitler/Ankara

TEKIN, Y., (2016), 'Cumhurbaşkanlığı Hükümet Sisteminde Kamu Denetimi Model Önerisi”, Ombudsman Akademik, (5), ss. 137-158.

TUNCEL, G., (2013), Osmanlıdan Cumhuriyete Türkiye'de Siyasal Hayat, Ed: Ahmet Karadağ, Orion Kitabevi,Altındağ/Ankara, ss. 223-292.

TUNÇ, A., (2019), Cumhurbaşkanlığı Hükümet Sistemi ve Yeniden Yapılanan Türk Kamu Yönetimi, Dora Basın Yayın Dağıtım, Osmangazi/Bursa.

TUNÇ, Ahmet v.d., (2018), 'AAzerbaycan Türkiye Siyasal Sistemlerinin Karşılaştırılması',, VII. Uluslararası Sempozyum idealden Gerçeğe Toplum ve Siyaset, Bilsam, ss. 64-73.

TURAN, A. M., (2018), 'Türkiye’nin Yeni Yönetim Düzeni: Cumhurbaşkanlı̆̆ı Hükümet Sistemi', Social Sciences Research Journal, 7 (3), ss. 42-91.

TÜRK, H. S., (2006), 'Seçim, Seçim Sistemleri ve Anayasal Tercih, ’Anayasa Yargısı Dergisi, 23 (0), ss. 75133.

UZUN, C. D., (2018), '‘6771 Sayılı Kanunla Anayasada Yargıyla İlgili Yapılan Düzenlemeler’, Uyuşmazlık Mahkemesi Dergisi, (11), ss. 409-433.

YAYLA, A., (2015), Karşılaştırmalı Siyasal Sistemler, Adres Yayınları, İskitler/Ankara.

YAYMAN, H., (2016),Türkiye'de Devlet Reformu ve Başkanlık Sistemi, Doğan Kitap, Beylikdüzü/İstanbul.

1 nolu Cumhurbaşkanlığ Kararnamesi, https://www.mevzuat.gov.tr/MevzuatMetin/19.5.1.pdf

2839 sayılı Milletvekili Seçimi Kanunu, https://www.mevzuat.gov.tr/MevzuatMetin/1.5.2839.pdf, (18.05.2020).

6271 Sayıl1 Kanun, http://www.ysk.gov.tr/doc/mevzuat/dosya/1581/6271.pdf, (14.05.2020).

6771 sayılı Anayasa Değişikliği Kanunu https://www.tbmm.gov.tr/kanunlar/k6771.html, (20.05.2020).

7102 Sayılı Kanun, https://www.resmigazete.gov.tr/eskiler/2018/03/20180316-28.htm, (26.05.2020). 